\title{
The short life of the Hoyle organ of Sepia officinalis: formation, differentiation and degradation by programmed cell death
}

\author{
Norbert Cyran • Anna Palumbo • Waltraud Klepal - Erica A. G. Vidal • \\ Yannick Staedler · Jürg Schönenberger · Janek von Byern
}

Received: 27 September 2016/Revised: 1 June 2017/ Accepted: 30 June 2017/Published online: 10 July 2017

(C) The Author(s) 2017. This article is an open access publication

\begin{abstract}
Cephalopods encapsulate their eggs in protective egg envelopes. To hatch from this enclosure, most cephalopod embryos release egg shell-digesting choriolytic enzymes produced by the Hoyle organ (HO). After hatching, this gland becomes inactive and rapidly degrades by programmed cell death. We aim to characterize morphologically the development, maturation and degradation of the gland throughout embryonic and first juvenile stages in Sepia officinalis. Special focus is laid on cell death mechanisms and the presence
\end{abstract}

Guest editors: Erica A. G. Vidal, Ian G. Gleadall \& Natalie Moltschaniswskyi / Advances in Cephalopod Ecology and Life Cycles

\section{N. Cyran $(\bowtie) \cdot$ W. Klepal}

Core Facility Cell Imaging and Ultrastructural Research, Faculty of Life Sciences, University of Vienna, Vienna, Austria

e-mail: norbert.cyran@univie.ac.at

\section{A. Palumbo}

Department of Biology and Evolution of Marine

Organisms, Stazione Zoologica Anton Dohrn, Naples, Italy

\section{E. A. G. Vidal}

Center for Marine Studies, University of Parana - UFPR, Pontal do Parana, Brazil

Y. Staedler · J. Schönenberger

Division of Structural and Functional Botany, Department of Botany and Biodiversity Research, University of

Vienna, Vienna, Austria of nitric oxide synthase during gland degradation. Hatching enzyme has been examined in view of metallic contents, commonly amplifying enzyme effectiveness. $\mathrm{HO}$ gland cells are first visualized at embryonic stage 23; secretion is observed from stage 27 onwards. Degradation of the HO occurs after hatching within two days by the rarely observed autophagic process, recognized for the first time in cephalopods. Nitric oxide synthase immunopositivity was not found in the HO cells after hatching, suggesting a possible NO role in cell death signalling. Although the HO 'life course' chronology in S. officinalis is similar to other cephalopods, gland degradation occurs by autophagy instead of necrosis. Eggs that combine a large perivitelline space

J. von Byern

Max F Perutz Laboratories, Centre for Integrative Bioinformatics Vienna, University of Veterinary Medicine, Medical University of Vienna, University of Vienna, Vienna, Austria

J. von Byern

Ludwig Boltzmann Institute for Experimental and Clinical Traumatology, Austrian Cluster for Tissue Regeneration, Vienna, Austria 
and multi-layered integument seem to require a more complex and large gland system.

Keywords Hatching gland · Autophagy $\cdot$ Nitric oxide $\cdot$ Nitric oxide synthase

\section{Introduction}

Cephalopods have a great variety of egg encapsulation mechanisms that can consist of from a single chorionic coat without protective jelly envelopes in octopodiformes to a multi-layer spirally coiled jelly coat in most decapodiformes (von Boletzky, 1986). Eggs can be released individually or in egg masses, which size, shape, structure and consistency also vary substantially among species (von Boletzky, 1986, 1998).

The hatching gland in cephalopods, referred to as the HO (Hoyle organ) (Wintrebert, 1928; Yung Ko Ching, 1930), represents a co-adaptation of the embryo to overcome the barrier imposed by the egg envelopes, across which it has to move freely during hatching. A close association is expected between egg encapsulation design and the morphology of the $\mathrm{HO}$ (von Boletzky, 2012). Therefore, detailed information on the morphology and the process of formation and degradation of the HO should have special value in clarifying how the gland system has evolved among species with assorted encapsulation mechanisms. This in turn would provide a foundation for the understanding of the ecological and evolutionary significance of the HO.

In cephalopods, the $\mathrm{HO}$ is an epithelial organ restricted to the posterior part of the dorsal mantle surface. Shortly before hatching, the HO is fully developed and releases proteolytic enzymes (Denuce \& Formisano, 1982) that weaken the egg integument so that it becomes permeable to water, resulting in an increase in osmotic pressure within the perivitelline space (von Boletzky, 2003). Instantly after hatching, a bulk degradation of the gland takes place and is accomplished within a few hours to a few days (von Orelli, 1959).

The HO generally consists of only one type of glandular cells, which synthesize electron-dense granules, spherical to polygonal in shape (depending on the charging level) (Cyran et al., 2013). In several decapodiform species (e.g. Sepiella japonica Sasaki, 1929, Sepia officinalis Linnaeus, 1758, Loligo sp. Lamarck,
1798, Sepioteuthis lessoniana Férussac [in Lesson], 1831, Architeuthis sp. Steenstrup, 1857), these granules differ in the later stage of development by containing electron-lucent inclusions (Matsuno \& Ouji, 1988; Arnold \& Singley, 1989; Cyran et al., 2013) named "bipartite dense granules" (Arnold \& Singley, 1989).

No information is available on the metal ion content of the hatching enzyme of cephalopods and the environmental and biological factors that regulate its availability. Detailed examinations of hatching enzymes have been carried out for teleosts (Ogawa \& Ohi, 1968; Yamagami, 1973; Yasumasu et al., 1988). The fish-hatching enzyme, referred to as chorionase (Yamagami, 1973), was found to be composed of two distinct components, a chorion swelling HCE (high choriolytic enzyme) and a subsequent chorion-digesting LCE (low choriolytic enzyme); both enzymes contain $\mathrm{Zn}, \mathrm{Mg}$ and $\mathrm{Ca}$ (Yasumasu et al., 1988, 1989a, b). Marine trace metal concentrations and their availability are strongly influenced by anthropogenic effects such as ocean acidification that has the potential to cause chances in trace metals solubility (Gledhill et al., 2015). Even small changes in essential trace metal availability can have a significant impact on organism function (Eide, 1998; Morel et al., 2003; Stockdale et al., 2016). Moreover, changes in $\mathrm{pH}$ have the potential to severely impact the aerobic performance of cephalopods (Pörtner \& Zielinski, 1998), with late embryos and paralarvae being certainly more susceptible. Low $\mathrm{pH}$ values can even cause an ionic and acid-based imbalance that leads to changes in the bioaccumulation of metals (D'Aniello et al., 1989; Lacoue-Labarthe et al., 2011).

The three most common types of cytoplasm-degradative processes are apoptosis, necrosis and autophagy (Kerr et al., 1972; Wyllie et al., 1980; Clarke, 1990; Berry \& Baehrecke, 2007). In cases of bulk degradation of tissues or organs, mostly autophagic cell death (Arbeitman et al., 2002; Berry \& Baehrecke, 2007; Mcphee et al., 2010) or necrosis-like programmed cell death (Leist \& Jaattela, 2001; Guimaraes \& Linden, 2004) has been observed. However, genetically triggered cell death strategies are complex and exhibit overlapping characteristics, which moreover flexibly diverge according to environmental and metabolic influence (Galluzzi et al., 2012).

Currently, the HO-degradation process has not been satisfactorily investigated with respect to the executing cell death strategy. In Idiosepius sp. Steenstrup, 
1881, characterization of the degradation process to a specific cell death mode was first attempted (Cyran et al., 2015). The authors identified an unspecific degradation of the entire cytoplasm and the loss of desmosomes between the glandular cells (Cyran et al., 2015) and hypothesized that this occurred via a hybrid cell death mode with an almost necrotic appearance. Similar characteristics were described earlier in Loligo pealei Lesueur, 1821 (Arnold \& Singley, 1989) and Sepiella japonica (Matsuno \& Ouji, 1988). Since the $\mathrm{HO}$ in $S$. officinalis is large in comparison to the aforementioned species and the egg is encapsulated in a thick multi-layer envelope (von Boletzky, 1986), we suppose to witness the rather effective autophagic cell death strategy, observed for instance several times during Drosophila development (Arbeitman et al., 2002; Berry \& Baehrecke, 2007).

Among the physiological mediators, nitric oxide (NO) has been reported to be involved in different processes in metazoans (Palumbo, 2005; Comes et al., 2007; Castellano et al., 2014; Migliaccio et al., 2014). This gaseous molecule, synthesized from L-arginine by the enzyme NO synthase (NOS), plays key roles in neurotransmission, defence system and development in S. officinalis (Palumbo et al., 2000; Fiore et al., 2004; Di Cristo et al., 2007; Mattiello et al., 2010, 2012, 2013). The spatial pattern of NO and NOS is very dynamic during cuttlefish development (Mattiello et al., 2012). An initial weak NO signal and NOS immunopositivity have been detected in the HO area at embryonic stage 26 (Mattiello et al., 2012). As development proceeds (stages 28-29), the NO signal is amplified in the anchor-shaped HO area. Also the density of NOS-immunopositive cells increases in the $\mathrm{HO}$ between stages 28 and 29. Considering the role of $\mathrm{NO}$ as cell death inhibitor (Leise et al., 2004), an increase in NO levels in the $\mathrm{HO}$ at late stages would ensure enzyme synthesis until hatching occurs. In this context, we would expect a dramatic decline in NO concentration after hatching and, consequently, activation of cell death signals and glandular degradation.

The aim of this study is to determine the first morphological indications for cell proliferation associated with the $\mathrm{HO}$, to track the morphological differentiation of the $\mathrm{HO}$ cells and the associated ciliary cells throughout their lifetime and to characterize and define the cell death processes by means of morphological criteria. Additionally, NOS detection by immunohistochemistry has been carried out on the
$\mathrm{HO}$ to examine the NO presence during $\mathrm{HO}$ degradation. A first enquiry into the involvement of metallic components in hatching enzymes in cephalopods also has been performed on mature gland content (embryonic stage 29) and contrasted to available data for metal ions in hatching enzymes of teleosts. We use $S$. officinalis as a "model" because its embryonic development is well described (von Orelli, 1959; Fioroni, 1990; Nixon \& Mangold, 1998; von Boletzky et al., 2016) and both the embryo and the hatching gland structure are relatively large compared to those of loliginids and octopods.

\section{Materials and methods}

\section{Embryo collection}

Fertilized eggs laid by S. officinalis females were allowed to develop in tanks with oxygenated sea water $\left(20^{\circ} \mathrm{C}\right.$; pH 8.1 ; salinity $\left.38 \mathrm{ppt}\right)$ at the Marine Resources for Research service of the Zoological Station Anton Dohrn. Different embryonic stages (from 20 to 30, according to Lemaire (1972) as well as 1- and 2-day-old juveniles were selected. The embryos were isolated from the egg capsule, vitelline layers and chorion and anesthetized in 3\% ethanol.

Fixation and microscopy

For ultrastructural analyses, the egg layers and animals were fixed in $2.5 \%$ glutaraldehyde with $0.1 \mathrm{M}$ sodiumcacodylate buffer ( $\mathrm{pH} 7.4$, plus $10 \%$ sucrose) for $5 \mathrm{~h}$ at $25^{\circ} \mathrm{C}$ and post-fixed for $1.5 \mathrm{~h}$ in $1 \%$ osmium tetroxide with $0.1 \mathrm{M}$ buffer solution and dehydrated in a graded series of ethanol. For TEM (transmission electron microscopy), the samples were embedded in Epon (Agar 100 resin); ultrathin sections (50-70 nm) were mounted on copper slot grids coated with formvar in dioxane, stained with gadolinium triacetate (Nakakoshi et al., 2011) and lead citrate (Reynolds, 1963) and examined in a Zeiss Libra 120 with $\mathrm{LaB}_{6}$ filament and a bottom mount camera Olympus Sharp:eye TRS $(2 \times 2 \mathrm{k})$. For SEM (scanning electron microscopy), the samples were washed several times in $100 \%$ acetone, dried in a critical point drier (Leica EM CPD 300 ), mounted on stubs, coated with gold in a sputter coater (JEOL JFC 2300 HR), and viewed in a JEOL IT 300 . 
For analyses of the elemental composition, semithin sections $(2.5 \mu \mathrm{m})$ of the resin blocks were prepared for EDX (energy-dispersive X-Ray tomography) with an EDAX System (Software Team, Version 4.3, Co. Ametek Germany) on the SEM. Additionally, sections of $40 \mathrm{~nm}$ thickness were mounted on copper grids for EELS (electron energy loss spectroscopy) measurements and EFTEM (energy filtered TEM) mapping on the TEM Zeiss Libra 120 with an in-column Omega filter.

For $\mu \mathrm{CT}$ (micro-computed tomography), the glutaraldehyde-fixed samples were washed in aqua bidest and dehydrated in a graded series of ethanol. Subsequently, the samples were contrasted for $36 \mathrm{~h}$ in $1 \%$ (w/v) PTA (phosphotungstic acid) in EtOH. The animals were imaged with an Xradia MicroXCT system $(90 \mathrm{keV} / 8 \mathrm{~W}$ tungsten $\mathrm{X}$-ray source, cooled $1 \mathrm{k} \times 1 \mathrm{k}$ CCD camera).

Nitric oxide synthase detection

Tissues of just hatched juvenile were prefixed in $4 \%$ PFA (paraformaldehyde) in PBS (phosphate buffered saline, $0.1 \mathrm{M}, \mathrm{pH} 7.4$ for $2 \mathrm{~h}$ at $25^{\circ} \mathrm{C}$ ), washed three times in PBS and then embedded in albumin-gelatine. After fixation overnight in $4 \%$ formalin and several washings in distilled water, slices of $100 \mu \mathrm{m}$ sections were obtained using the vibratome Leica VT1200S (Leica Biosystems GmbH, Germany). Primarily, an antibody against universal NO synthase (uNOS) (Co. Thermo Scientific USA, Cat. Nr. PA1-039) was used at a dilution of 1:300; then the secondary Alexa Fluorlabelled antibody (Invitrogen USA, Cat. Nr. A 11008) was used at a dilution of 1:500 (see protocol in Wollesen et al., 2009). Imaging was carried out with a laser confocal microscope Leica TCS SP5X with a white light laser (excitation wavelength $488 \mathrm{~nm}$, detected at 510-530 $\mathrm{nm}$ ).

\section{Results}

Morphological transformation of the egg and its integument during development

The eggs of $S$. officinalis consist of the chorion membrane, several vitelline layers (Fig. 1A) and a multi-layered egg capsule with a fixation ring. All layers show a filamentous organization with a strand
Fig. 1 Egg composition of Sepia officinalis. A The egg is enclosed in a chorion membrane and several vitelline layers (stage 23, egg capsule removed). B A multi-layered egg capsule composed of numerous layers (outermost on top) serves as outer protection (stage 23), whereby a clear distinction between capsule and vitelline layers cannot be established. C The outermost capsule layers contain the highest amount of incorporated ink droplets and other, exogenous inclusions, presumably bacteria (arrowheads) (stage 23). The inset points to the internal, variably orientated, filamentous structure, which is emphasized with stronger contrast. D The left-hand layers are highly compressed, whereas the inner layers (bracket) are intermediated by lower density areas (stage 30). ch chorion, id ink droplet, $v i$ vitelline layer. Scale bars $200 \mu \mathrm{m}(\mathbf{A}), 100 \mu \mathrm{m}$ (B), $1 \mu \mathrm{m}(\mathbf{C}), 10 \mu \mathrm{m}(\mathbf{D})$

diameter of about $10 \mathrm{~nm}$. The layers of the egg capsule as well as the vitelline layers contain ink droplets and other exogenous inclusions (Fig. 1B-D). The outermost capsule layers seem to exhibit the highest abundance of ink (Fig. 1B). A section through the entire egg integument did not reveal any morphological differences between the vitelline layers and those of the capsule.

Up to embryonic stage 24 , the egg integument exhibits a predominantly uniform density (Fig. 1B), while before hatching the individual layers are compressed and clearly distinguishable (stage 30, Fig. 1D). Areas with material of lower density appear between the vitelline layers, which are not observable between the capsule layers (Fig. 1D). These less dense areas almost lack ink and other inclusions.

During the last 2-3 days prior to hatching, the egg integument expands by about $30 \%$. The vitelline layers and internal parts of the egg capsule disintegrate increasingly until at hatching only the outermost capsule layers and the chorion membrane remain, while the layers in-between lose their cohesion completely. Steady body movements of the embryo before hatching finally lead to a collapse of the egg integument.

\section{HO development}

The following section describes the chronological sequence of the formation and differentiation of the $\mathrm{HO}$ cells, the synthesis and secretion of the glandular content and the subsequent cellular decay of the organ. The development of the HO appears to be asynchronous: initially, the lateral bands arise, starting from the central crossing point of the anchor (Fig. 2A, 


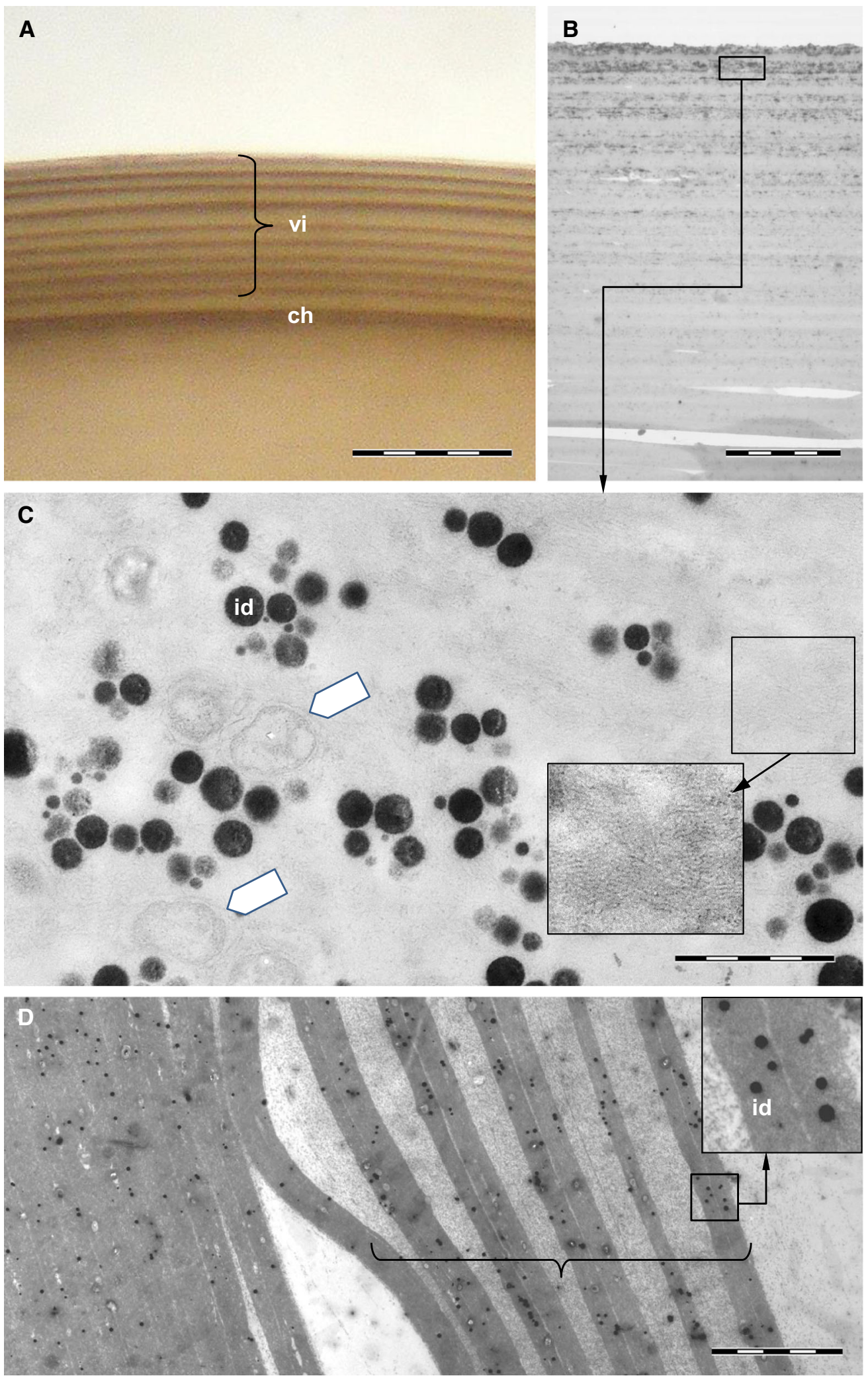



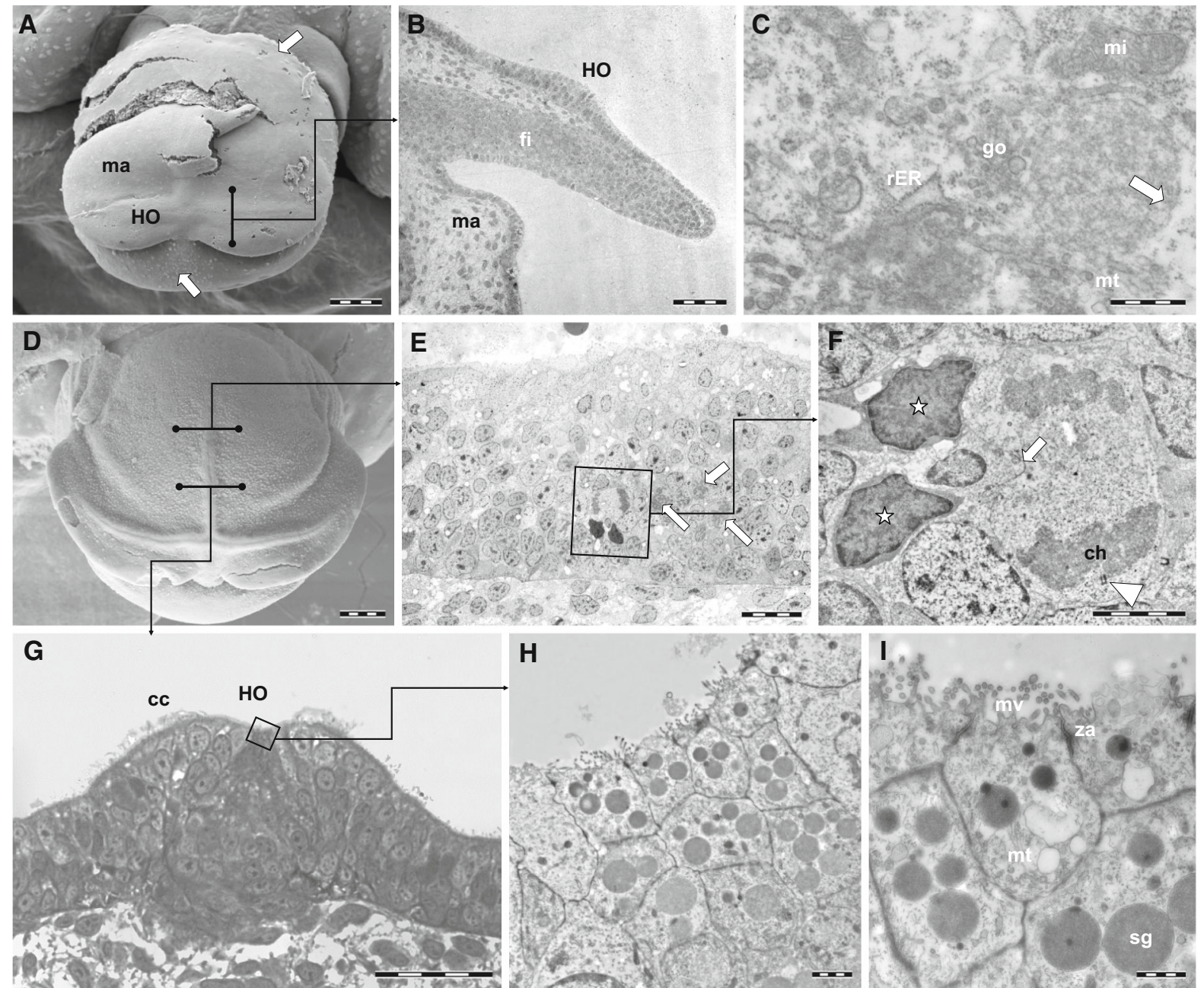

Fig. 2 Embryonic stages 23 (A-C) and 24 (D-I): A at stage 23, the lateral bands of the Hoyle organ are clearly pronounced in relation to the normal mantle epithelium, while only a short part of the dorsal band has developed so far. Ciliary tufts are visible below the posterior mantle pole and along the anterior mantle edge (arrows). B The development of the Hoyle organ can be recognized by the elevated epithelium surface. Initial accumulations of secretory granules already occur in the apical region of the gland cells. C The synthesizing organelles display a high activity in assembling secretory material. Tubules are aligned along the vertical cell axes. The arrow shows the migration direction of the granules (towards the apical cell pole). D At stage 24 , the three bands of the Hoyle organ are clearly visible externally. Ciliary tufts cover the whole mantle evenly. E Shows a part near the distal end of the dorsal band at stage 24, where a very initial differentiation of the Hoyle organ cells can be observed. The cell height has not yet increased but within the epithelium several cell divisions can be observed by means of the beginning chromatin condensation (arrows). F A constricted nucleus (arrow) in telophase with a centriole at the nuclear pole (arrowhead). The aborning Hoyle organ cells are accompanied by a degradation of other epithelium cells, which display a conspicuous degradative chromatin condensation, apparently associated with cell death (stars). G Cross section of a proximal region of the dorsal band. The recessed middle part displays the tips of the secretory cells, accompanied laterally by continuous ciliated epithelial cells. H Distally in the secretory cells, accumulations of spherical secretory granules are evident. Basally in the cell the granules have low density but condense increasingly during their migration towards the cell tips while becoming more electron dense and smaller in size (finally $1-1.5 \mu \mathrm{m})$. I The movement of the granules is apparently realized by longitudinal microtubules acting as sliding elements. $c c$ ciliated cells, $c h$ condensed chromatin, $f$ fin, go Golgi bodies, HO Hoyle organ, ma mantle, $m i$ mitochondrion, $m t$ microtubules, $m v$ microvilli, $r E R$ rough endoplasmic reticulum, $s g$ secretory granules, za zonula adherens. Scale bars $200 \mu \mathrm{m}$ (A, D), $50 \mu \mathrm{m}(\mathbf{B}), 1 \mu \mathrm{m}(\mathbf{C}, \mathbf{I}), 2 \mu \mathrm{m}(\mathbf{E}, \mathbf{H}), 5 \mu \mathrm{m}(\mathbf{F}), 50 \mu \mathrm{m}(\mathbf{G})$ 

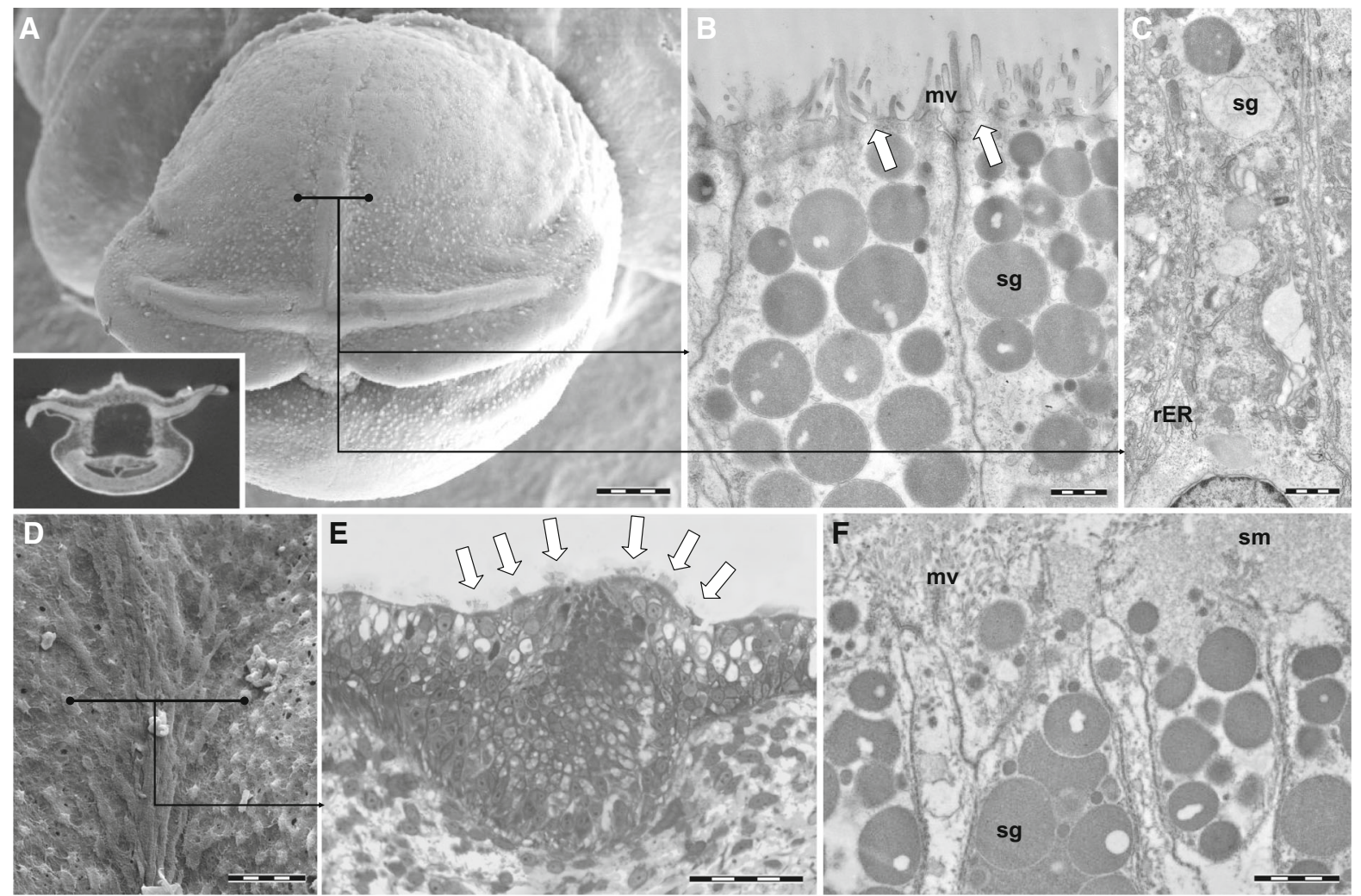

Fig. 3 Embryonic stages 25-26 (A-C) and 27 (D-F): A posterior view of the Hoyle organ (SEM) and an associated virtual micro-CT cross section (inset). B The granules have a uniform density but electron transparent areas indicate the beginning bipartity of the granules. Microvilli cover the cell surface. C Above the nucleus the synthesis is still highly active within the secretory cells, indicated by the bulk of endoplasmic reticulum and the assembling secretory granules. D At stage 27,

D) at stage 23. The dorsal band occurs later (not before stage 24), while the lateral bands continuously extend sideways (Fig. 2D). As a clear indication of gland development, the epithelium height increases locally from 15 to $30 \mu \mathrm{m}$ (Fig. 2A, B). In the apical cell area, accumulations of electron-dense secretory droplets appear in the emerging HO cells. Basally and centrally within the secretory cells, the synthesis of the hatching enzymes takes place, as evidenced by the presence of the rough endoplasmic reticulum and Golgi bodies. The first secretory granules, accompanied by microtubules, can already be observed at this early stage (Fig. 2C).

At stage 24, a high abundance of dividing cells signalizes an epithelial reorganization, also at the distal ends of the dorsal band (Fig. 2D-F). In contrast the dispersion of the ciliated cells, lining the dorsal band of the Hoyle organ, changes to a feather-like pattern. E The cross section of this region illustrates the presence of several rows of ciliated cells (arrows). F First indications of a secretory process are obvious at stage 27. $m v$ microvilli, $r E R$ rough endoplasmic reticulum, $s g$ secretory granules, $s m$ secreted material. Scale bars $200 \mu \mathrm{m}(\mathbf{A}), 1 \mu \mathrm{m}(\mathbf{B}), 2 \mu \mathrm{m}(\mathbf{C}, \mathbf{F}), 50 \mu \mathrm{m}(\mathbf{D}), 20 \mu \mathrm{m}(\mathbf{E})$

to the arising gland cells, neighbouring epithelial cells show signs of apoptosis such as nuclear chromatin condensation as well as cytoplasm compression and vacuolization (Fig. 2F). At this stage, near the $\mathrm{HO}$ crossing point a local heightening of the epithelium, twice of that of the regular cells, can be observed (Fig. 2D, G), as was seen earlier for the lateral bands. In cross section, the secretory cells of the gland form a triangular shape. The secretory material accumulates in membrane-bound spherical granules $(1-1.5 \mu \mathrm{m}$ in diameter) apically in the cells (Fig. 2H). Abundant microtubules illustrate the migratory movements of the granules from the basal synthesis region towards the apical cell surface (Fig. 2I). On the apical pole of the secretory cells are numerous microvilli (approximately $1 \mu \mathrm{m}$ in length, sometimes branched). Beside 


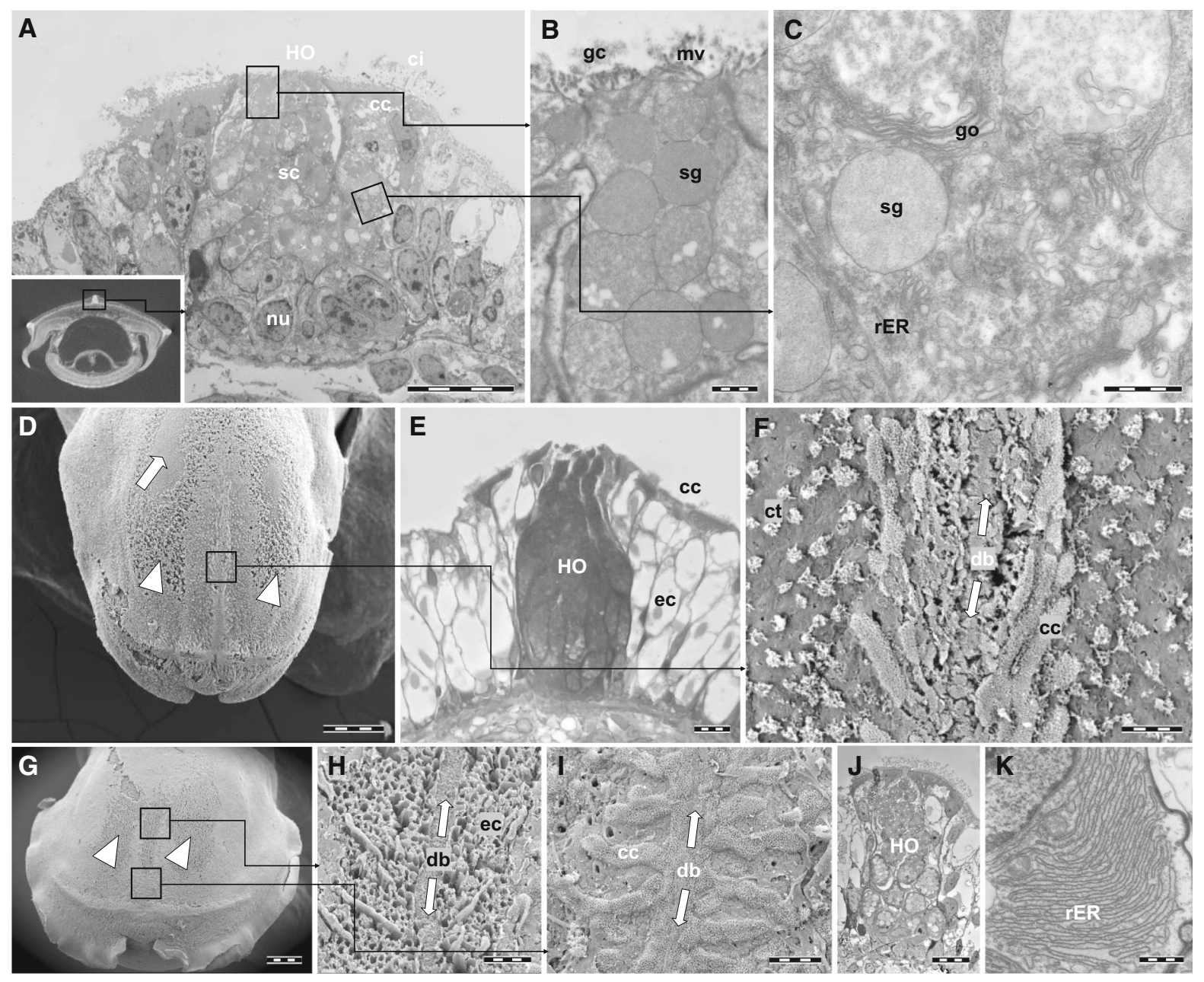

Fig. 4 Embryonic stages 28 (A-C), 29 (D-F) and 30 (G-K): A cross section of the Hoyle organ showing the mature gland cells and the laterally bordering ciliated cells (stage 28). The inset shows a related virtual micro-CT section. B Apical pole of a secretory cell, tightly packed with granules and covered with microvilli and glycocalyx on the surface. $\mathbf{C}$ Synthesis area of a gland cell showing endoplasmic reticulum, Golgi bodies and forming secretory granules. D SEM illustration of a stage 29 embryo. The erosion of the epithelial cells is clearly visible laterally from the dorsal band (arrow heads). Some areas completely lack epithelial cells (arrow) and expose the basal membrane. E Cross section (stage 29) showing a distinct reduction of the gland in relation to stage 28 , effected by continuous secretion and stagnating synthesis. Moreover, the epithelial cells tend increasingly to be empty. F Detail of the surface view illustrating the ciliated cells around the Hoyle organ which form a feather-like pattern. The arrows indicate the

numerous scattered ciliary fields across the mantle surface, a continuous lateral boundary of the secretory cells by ciliated epithelial cells starts to be present (Fig. 2G). secretory cell areas. G SEM illustration of a stage 30 embryo. The areas of eroded epithelial cells are labelled by arrow heads. $\mathbf{H}$ The apical areas of these epithelial cells are completely dissolved. The arrows indicate the secretory cell areas. I An intact epithelium area near the posterior pole with the final appearance of the ciliated gland border before depletion of the organ and its accompanying structures. The arrows indicate the secretory cell areas. J Cross section of the Hoyle organ (stage 30). The volume of the secretory cells is significantly decreased. K Although the synthesis seems to be finished, the endoplasmic reticulum still appears intact. $c c$ ciliated cells, $c i$ cilia, $c t$ ciliary tufts, $d b$ dorsal band, $e c$ epithelial cells, $g c$ glycocalyx, go Golgi bodies, $H O$ Hoyle organ, $m v$ microvilli, $n u$ nucleus, $r E R$ rough endoplasmic reticulum, $s c$ secretory cells, $s g$ secretory granules. Scale bars $20 \mu \mathrm{m}(\mathbf{A}, \mathbf{E}, \mathbf{J}), 1 \mu \mathrm{m}(\mathbf{B}, \mathbf{C}, \mathbf{K}), 500 \mu \mathrm{m}(\mathbf{D}, \mathbf{G})$, $50 \mu \mathrm{m}(\mathbf{F}, \mathbf{H}, \mathbf{I})$. Image 4A reprinted from Cyran et al. (2013) with permission from Elsevier

With ongoing embryonic development (stages 25-26) (Fig. 3A), the apical cell areas show large accumulations of secretory granules (Fig. 3B). Furthermore, increasing condensation leads to 'empty 

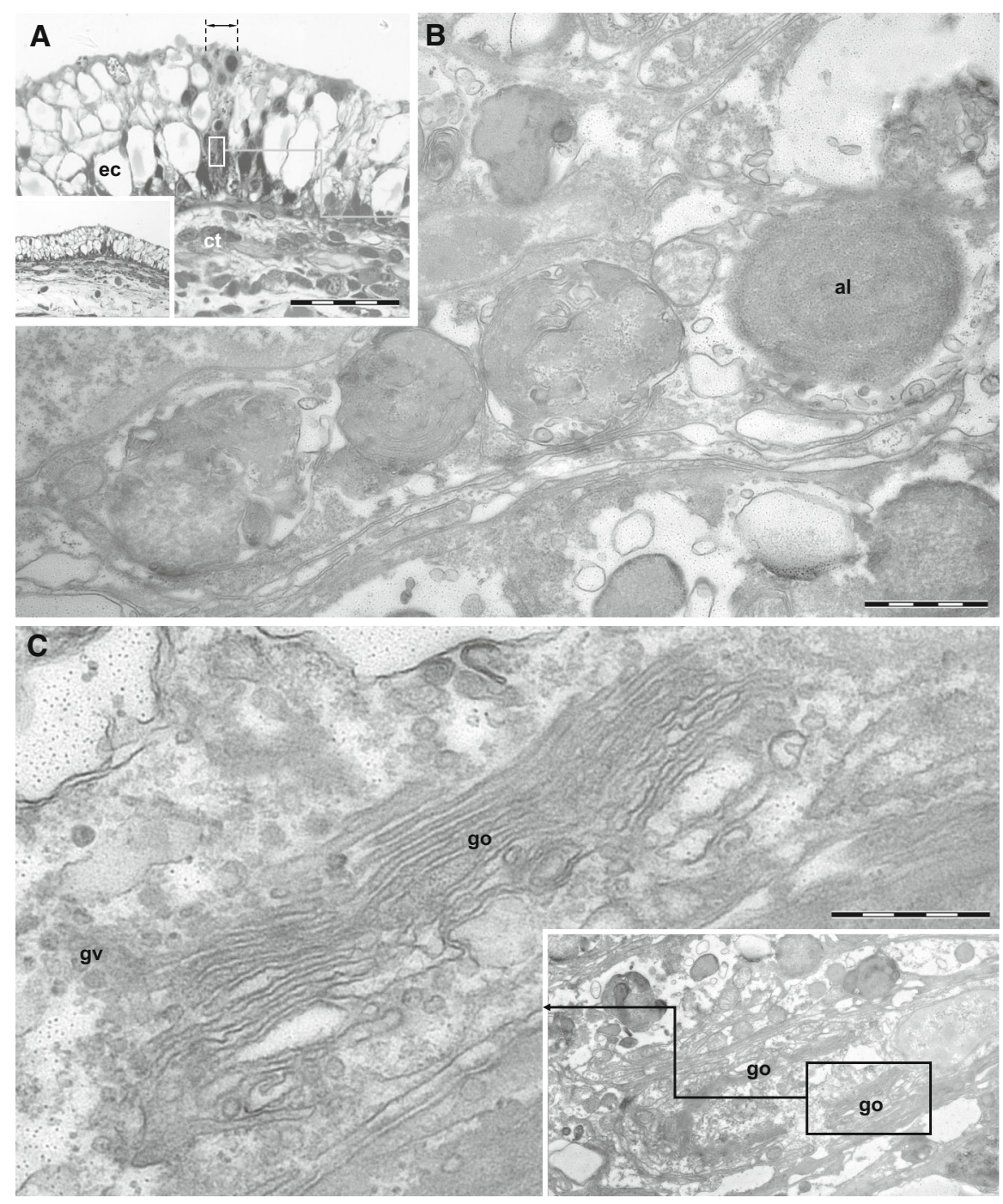

Fig. 5 Degradation of the Hoyle organ, one day after hatching. A Light microscopic image of the dorsal mantle epithelium. The remaining Hoyle organ (label) is considerably reduced after one day. B The secretory cells are characterized by autolysosomes containing membrane stacks, mitochondria, ribosomes and parts of granules. The single-membraned autolysosomes illustrate the

areas' in the granules, termed earlier as 'bipartite granules'. As the replenishment with fresh material decreases within the cell apices, the previously dominant microtubules are not evident anymore. Within the cell base, the enzyme synthesis is proceeding as observable by means of active protein synthesis, vesicular transport and obvious assembling of secretory droplets (Fig. 3C).

Around stage 27 (Fig. 3D-F), the upper two-thirds of the gland cells are largely filled with granules and stage after the cytoplasm-incorporating autophagosome fuses with a lysosome and is subsequently digested. C During autophagic degradation, Golgi bodies are reactivated and bud off numerous vesicles. al autolysosome, $c t$ connective tissue, $e c$ epithelial cells, go Golgi bodies, gv Golgi vesicles. Scale bars $50 \mu \mathrm{m}(\mathbf{A}), 1 \mu \mathrm{m}(\mathbf{B}), 500 \mathrm{~nm}(\mathbf{C})$

the ongoing condensation intensifies their bipartite character, especially in the distal cell areas (Fig. 3F). While the synthesis of granules in the basal cell parts continues unchanged, the first indications of secretory activity are observable as cell content is found deposited outside the body surface (Fig. 3F).

At stage 28, the glandular area of the $\mathrm{HO}$ reaches its largest dimension (in cross section) (Fig. 4A) with a height of $50 \mu \mathrm{m}$, twice that of the regular epithelium cells, and a width of $40 \mu \mathrm{m}$. The ciliated lateral 
boundary cells as well as their glycocalyx are particularly pronounced at this stage (Fig. 4A, B). In cross section, around five gland cells are neighbouring each other within a band and are tightly filled with secretory material up to their distal poles (Fig. 4B). The gland appears at this stage to be more barrel-shaped than triangular in cross section. No evidence of an interruption in the synthesis process was observable (Fig. 4C).

The following embryonic stages are characterized by a regression of the HO, caused by continuous secretion in combination with a reduced synthesis rate. At stage 29 (Fig. 4D-F), the secretory cells are substantially condensed and increasingly narrower (Fig. 4E). Major parts of the remaining secretory material are released during stage 30 (Fig. 4J) before hatching occurs. The rough endoplasmic reticulum below the nucleus still appears intact (Fig. 4K), although indications of material synthesis could no longer be observed.

\section{HO degradation}

After hatching, the remnants of the secretory material and cell organelles degrade. The secretory cells, with an overall width of $40 \mu \mathrm{m}$ at stage 28 , are collapsed to a joint width of $10 \mu \mathrm{m}$ (Fig. 5A). They contain numerous distinct single-membraned autophagic vacuoles (autolysosomes) enclosing cytoplasmic elements such as membrane stacks, mitochondria, ribosomes and secretory granules (Fig. 5B). Concomitantly, the increase of Golgi bodies and an abundant budding of Golgi vesicles are evident (Fig. 5C).

Two days after hatching, the previously prominent elevation of the HO has disappeared almost entirely and only a slightly elevated (about $20 \mu \mathrm{m}$ ) ridge is left, provoked by the still thickened connective tissue (Fig. 6A). The cellular residues are further reduced and restricted to a narrow area in the basal parts of the cells (Fig. 6B). Ingested organelles in the autolysosomes have been degraded almost beyond recognition (Fig. 6C), and the recently emerging Golgi bodies have already disappeared.

Nitric oxide synthase

Newly hatched embryos showed no NOS immunopositivity within the gland cells of the HO (Fig. 7). By contrast, immunofluorescence could be observed in

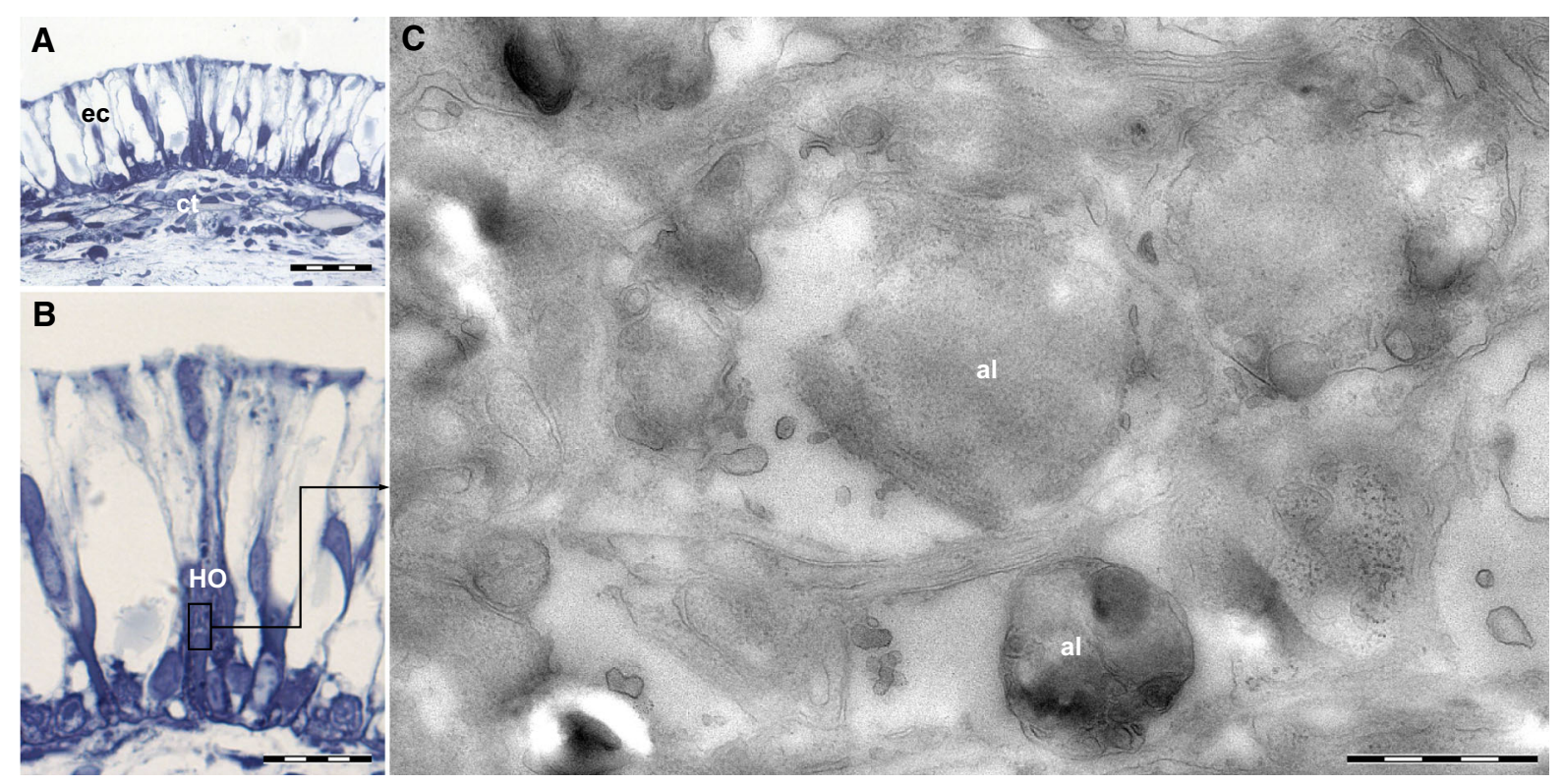

Fig. 6 Degradation of the Hoyle organ in a two-day-old juvenile. A, B Overview of the regressing gland. The connective tissue is still slightly elevated. C Detail of the degrading secretory cells showing a late phase of digesting autolysosomes.
The previously massively increased Golgi body abundance, visible one day after hatching, no longer exists. al autolysosome, ct connective tissue, ec epithelial cells, $\mathrm{HO}$ Hoyle organ. Scale bars $50 \mu \mathrm{m}(\mathbf{A}), 20 \mu \mathrm{m}(\mathbf{B}), 1 \mu \mathrm{m}(\mathbf{C})$ 


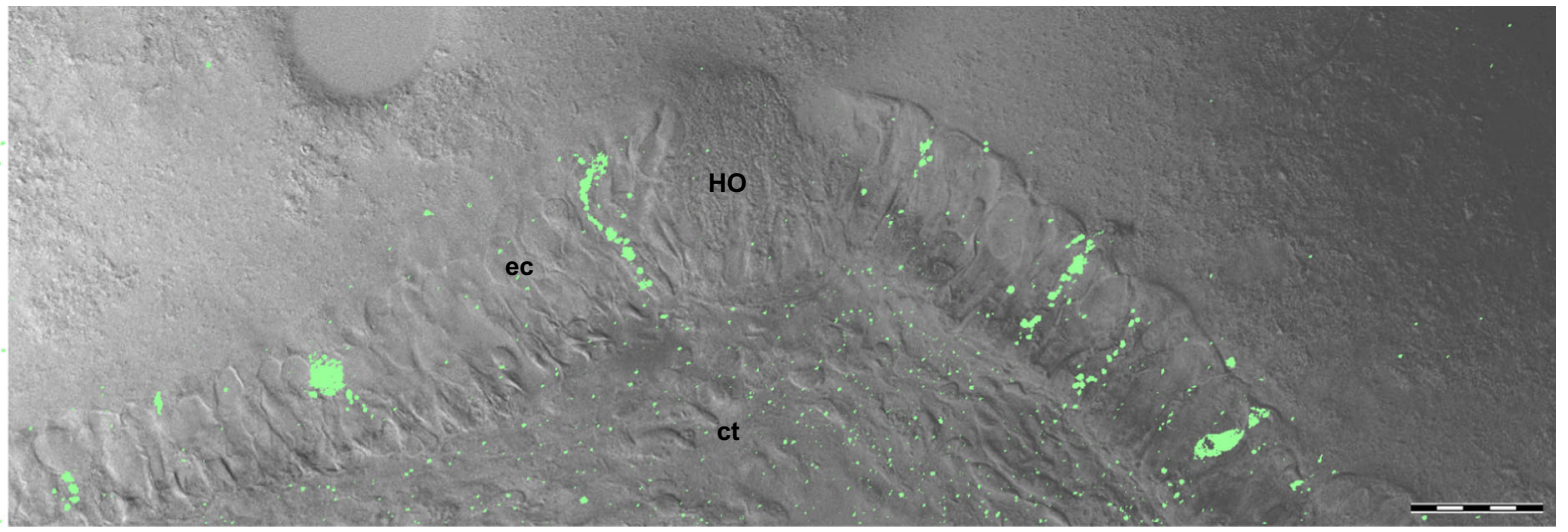

Fig. 7 Vibratome cross section $(100 \mu \mathrm{m}$ thick) of the HO with the surrounding epithelium and connective tissue in a hatched specimen. Positive labelling of NOS (overlaid with a light microscopic image) is highlighted in green, showing a high

some individual epithelial cells in close proximity to the $\mathrm{HO}$ and with a scattered dispersion within the connective tissue.

Related modification of the normal mantle epithelium

From stage 28 onwards, an increasing erosion of the regular epithelial cells could be observed on the dorsal mantle surface. Apart from a few residues of secretory material, the cells are empty (Fig. 4E) in contrast to presence within some epithelium cells and an even dispersion in the connective tissue. By contrast, the cells of the $\mathrm{HO}$ are not stained. $c t$ connective tissue, ec epithelial cells, HO Hoyle organ. Scale bar $100 \mu \mathrm{m}$

earlier stages (Figs. 2G, 3E, 4A). Numerous epithelial cells appear abraded or even completely etched off (Fig. 4D, F-I), in particular those close to the dorsal band of the $\mathrm{HO}$ (Fig. 4H). However, indications for a triggered cell degradation mechanism pertaining to the epithelial cells could not be observed in this study.

Ciliated epithelium cells and their alterations

Ciliated epithelium cells make up the abundant ciliary tufts (Fig. 8A) on the mantle and head, as well as the
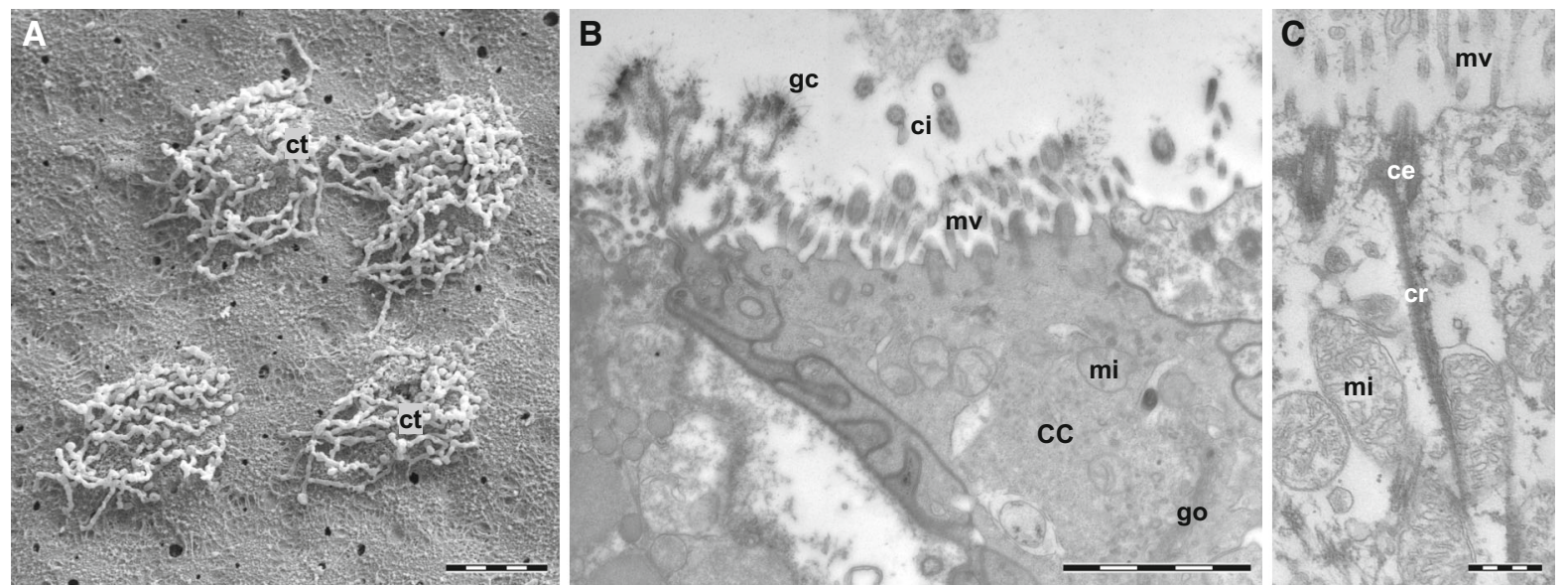

Fig. 8 Ciliated mantle epithelium cells. A SEM image of a group of ciliary tufts dorsally on the mantle (stage 22). B The ciliated cells are characterized by a small cell volume but a considerable dense cytoplasm, dense microvilli and a conspicuous glycocalyx (stage 28). C Later in development (late stage 30 ), the formerly dense cytoplasm of this ciliary tuft cell loosens. Indeed, the close association of the ciliary roots with mitochondria becomes visible. $c c$ ciliated epithelium cell, $c e$ centriole, $c i$ cilia, $c r$ ciliary root, $c t$ ciliary tuft, $g c$ glycocalyx, go Golgi bodies, $m i$ mitochondria, $m v$ microvilli. Scale bars $10 \mu \mathrm{m}$ (A), $2 \mu \mathrm{m}(\mathbf{B}), 500 \mathrm{~nm}(\mathbf{C})$. Image $8 \mathrm{C}$ reprinted from Cyran et al. (2013) with permission from Elsevier 
Table 1 EDX evaluation of metal contents (iron and copper) in the integument around the hatching gland according to the reference in Fig. 7A (embryonic stage 29 , Area 1-5) and in the egg integument (embryonic stage 24). The high error levels are caused by the low concentration of iron and copper in relation to the detection limits of this technique

\begin{tabular}{lllll}
\hline Measurement points & Element & Weight \% & Error \% \\
\hline \multirow{2}{*}{ Area 1 } & Negative control & Fe K & - & - \\
& & $\mathrm{Cu} \mathrm{K}$ & - & - \\
Area 2 & Regular epithelium cells & Fe K & - & - \\
& & $\mathrm{Cu} \mathrm{K}$ & - & - \\
Area 3 & Hoyle organ, secretory content & Fe K & 0.21 & 35.82 \\
& & $\mathrm{Cu} \mathrm{K}$ & 0.24 & 38.82 \\
Area 4 & Hoyle organ, synthesis area & Fe K & 0.19 & 32.29 \\
& & $\mathrm{Cu} \mathrm{K}$ & 0.16 & 59.90 \\
Area 5 & Connective tissue & Fe K & 0.15 & 45.24 \\
& & $\mathrm{Cu} \mathrm{K}$ & 0.13 & 60.02 \\
Egg integument & Fe K & 0.04 & 56 \\
& & $\mathrm{Cu} \mathrm{K}$ & 0.08 & 34.79 \\
\hline
\end{tabular}

ciliated HO boundary. Those cells differ from the regular epithelial cells by exhibiting a denser cytoplasm, a more electron-dense nucleus with sharply bounded nucleoli, numerous Golgi bodies and mitochondria but with a lower amount of cytoskeleton elements (Fig. 8B). The nucleus is frequently located in the apical cell region near the epithelial surface and the cytoplasm is then reduced to a thin margin. In some cells, ciliary roots appear to be connected to the outer membrane of the mitochondria (Fig. 8C). On the mantle surface, a glycocalyx (pronounced at stage 29 and later) with branching fibrous appendices adheres to the microvilli. Only the length of the microvilli differs between the cilia from the tuft $(10 \mu \mathrm{m})$ and those that are associated with the HO $(5 \mu \mathrm{m})$.

After hatching, both types of ciliated cells disappear simultaneously with the HO. While one day after hatching just a few remaining ciliated cells could be found, there is no evidence of the latter after two days.

SEM observations discovered an alteration in the pattern of ciliated cells on the mantle surface during embryonic development.

\section{HO periphery}

Along the secretory cells, the ciliary border appears at stage 24 , after the secretory cells assemble the first secretory droplets. Initially, a small band of cilia is established on each side of the gland. Beginning from stage 26 onwards, the ciliated area along the HO is no longer aligned in parallel to the secretory cells, but expands laterally in several short lines $(50-100 \mu \mathrm{m}$ length) in an increasing angle to the secretory cell bands $\left(15^{\circ}\right.$ at stage $27,20^{\circ}$ at stage $29,90^{\circ}$ at stage 30 ), resulting in a feather-like pattern which is clearly visible from stage 27 onwards (Figs. 3D, E, 4A, F, I).

\section{Ciliary tufts}

The ciliary tufts on the mantle surface have a relatively constant size of about $10 \mu \mathrm{m}$ and each of them belongs to one or a few epithelial cells. We observed changes in the number and distribution of these tufts. In the earliest observed stage (23), only the head is evenly covered with them. Dorsally, the mantle is almost free of ciliary tufts, except for some sporadic tufts along the anterior mantle edge. A band of these structures is present on the ventral mantle surface, beginning at the posterior pole (Fig. 2A). Later in development, the ciliated areas rapidly spread around the mantle. Up until stage 24 , the whole mantle is uniformly covered with ciliary tufts (Fig. 2D).

Trace metals in the embryonic tissue

In both the secretory cells of the hatching gland as well as in the subepithelial connective tissue, small amounts of copper $(0.24 / 0.13 \%)$ and iron $(0.21 /$ $0.15 \%$ ) (Table 1; Fig. 9) could be measured at embryonic stage 29; none of these metals were present in the regular epithelium cells. Measurements on the egg integument at embryonic stage 24 revealed approximately half the value for copper and a quarter of the value for iron in relation to the HO. Detailed EFTEM mapping shows the distribution of copper in the secretory granules of the gland (Fig. 9C). 

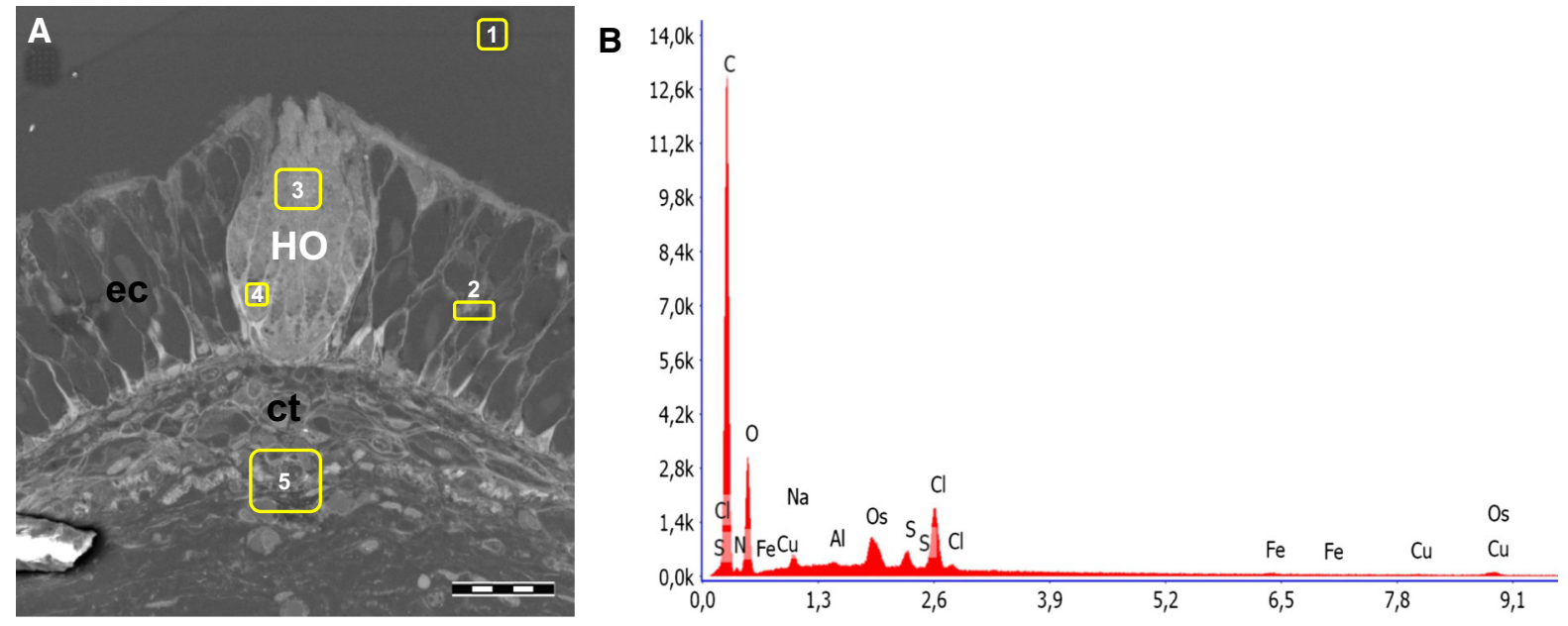

Fig. 9 Distribution of copper and iron in the Hoyle organ and adjacent tissues (embryonic stage 29), evaluated by energydispersive X-ray spectroscopy (EDX): A backscatter image indicating five measuring areas on a $2-\mu \mathrm{m}$-thick resin section. Point 1 is the negative control beyond the tissue without copper or iron. Point 2 is an almost empty epithelium cell, also lacking both metals. Points 3 and 4 (HO) as well as 5 (connective

\section{Discussion}

This study provides the first comprehensive information on the processes of formation, differentiation and degradation of the $\mathrm{HO}$ in S. officinalis. It indicates that the rarely observed autophagic cytoplasm-degradative process is responsible for the disappearance of the entire $\mathrm{HO}$ within two days after hatching. By nature, hatching and the days that follow represent a critical transitional period in the early life history of cephalopods pointed out by

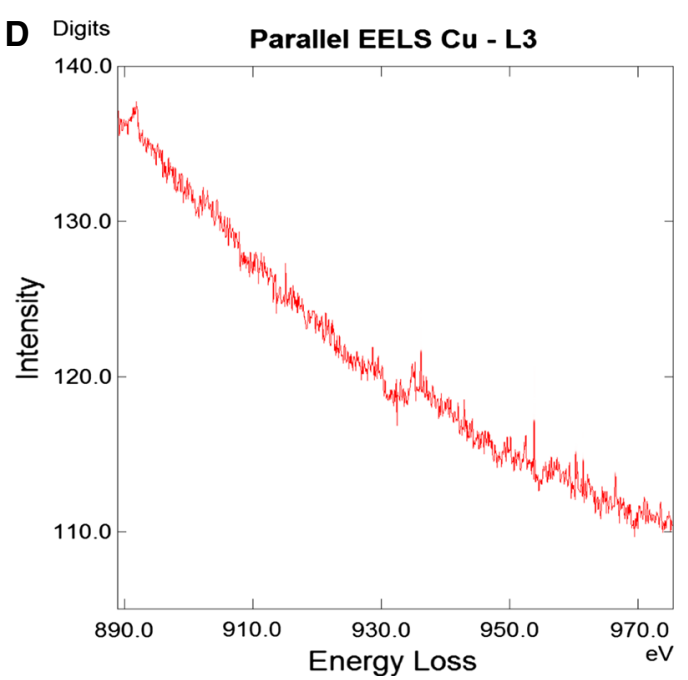

tissue) contain small amounts of iron and copper (Table 1). B EDX spectrum of point 3. C TEM image of granules of the Hoyle organ combined with an EFTEM copper distribution map in yellow. D EELS spectrum of a relating Hoyle organ granule. $c t$ connective tissue, ec epithelial cells, $H O$ Hoyle organ, sg secretory granules. Scale bars $50 \mu \mathrm{m}$ (A), $500 \mathrm{~nm}$ (C)

high mortalities (von Boletzky, 2003; Vidal et al., 2014). During this very short period, S. officinalis hatchlings go through complex morphological, ecological and behavioural milestones, such as the transition from endogenous (yolk) to exogenous (prey) food sources accompanied by maturation of the digestive gland and mastering predatory and swimming abilities (Boucaud-Camou et al., 1985; O'Brian, 2017). Thus, it is of significance that concurrently with these major events, the HO goes through complete degradation. 
The HO in S. officinalis late embryos is an anchorshaped conspicuous feature, containing relatively large amounts of enzymes to digest a multi-layer thick egg integument with large perivitelline space. These seem to be the main congruent features of the $\mathrm{HO}$ in all decapodiform cephalopods studied so far (von Boletzky, 2012; Cyran et al., 2013). The gland system, however, differs between species in its outer morphology. It is elevated in S. officinalis and most studied species, infolded in Loligo and accompanied by a terminal spine in Euprymna scolopes Berry, 1913 and Rossia macrosoma (Delle Chiaje, 1830) (von Boletzky, 1991; von Byern et al., 2016).

It is of evolutionary relevance, however, that substantial morphological dissimilarities occur between taxonomic groups. In octopodiformes, represented by Tremoctopus gracilis (Souleyet, 1852), Octopus vulgaris Cuvier, 1797 and Argonauta hians Lightfoot, 1786 , the HO gland system consists of a discreet single horizontal band with relatively few glandular cells, while in the later two species, it is not even clearly visible (Cyran et al., 2013). The eggs in this group lack protective envelopes and show limited chorionic expansion and thus perivitelline space, making late-stage embryos tightly surrounded by the chorion, what perhaps facilitates the action of $\mathrm{HO}$ enzymes. In comparison, in decapodiformes, the perivitelline space is in general large and there are many jelly layers to be also digested. A combination of large perivitelline space and a multi-layer egg integument seems to be a necessary prerequisite for a more complex and large gland system. In this regard, the HO seems to have evolved high complexity and importance in decapodiformes in general and in S. officinalis in particular.

\section{Egg integument}

The disintegration of the egg capsule and the vitelline layers appears to take place from the centre outwards in accordance with the proposed effect of the hatching enzymes. The first changes in the egg integument occur concomitantly with the first secretion of enzymes at stages 27-28. It has been shown that the increase of the chorionic space during late embryonic development leads to the shrinkage of the inner egg envelopes (Jecklin, 1934; Gomi et al., 1986; Cyran et al., 2013), whereby the individual layers become clearly visible in contrast to earlier developmental stages (Fig. 1D). The observed lower density areas between the vitelline layers are almost devoid of the inclusions located in the dense areas such as ink and bacteria. Since such inclusion-free areas were not observed at earlier embryonic stages, they apparently arise in the course of the reorganization of the egg integument.

\section{Enzyme production}

Initial alterations in the mantle epithelium with respect to the upcoming $\mathrm{HO}$ take place relatively early in embryonic development (embryonic stage 23) compared to other cephalopods (von Orelli, 1959; Arnold \& Singley, 1989; Cyran et al., 2013). This may be related to the large embryo and large perivitelline space of the egg. A large embryo size (Fioroni, 1978) should induce a comparatively large spatial expansion of the gland in relation to other teuthid or octopod species. A higher amount of egg shell weakening enzymes also should be required in view of the large perivitelline space (von Orelli, 1959) and the manylayered egg integument (von Boletzky, 1986).

Our observations confirm that the synthesis of enzymes occurs until shortly before hatching, as also observed for Loligo and Sepiella (Matsuno \& Ouji, 1988; Arnold \& Singley, 1989). The fact that unspent secretory material remains in the cells during hatching is due to the supposed high redundancy in enzyme volume to ensure hatching under all circumstances (von Orelli, 1959; von Boletzky, 2012).

Bipartite granules

We suppose that the less electron-dense areas in the secretory granules (Fig. 3B, F) appear as a consequence of the incremental material density. The condensed secretory material requires less volume, leaving voids in the granules. In contrast, Matsuno \& Ouji (1988) assumed the existence of two discriminative components as an explanation for the bipartity in granules of $S$. japonica. We could not find any evidence for the synthesis of two different secretory products within the $\mathrm{HO}$ cells of $S$. officinalis.

Evidences for autophagic cell death in the degrading $\mathrm{HO}$

Before the knowledge of the numerous metabolic triggering molecules within the cells (Tsukada \& 
Ohsumi, 1993; Thumm et al., 1994), electron microscopic imaging was the only way to investigate cellular degradation events in detail (Clark, 1957; Ashford \& Porter, 1962; Novikoff \& Essner, 1962). This technique is still reliable to classify cell death strategies by their morphological features before performing the subsequent molecular pathways analyses (Eskelinen, 2008; Eskelinen et al., 2011).

Previous observations of the degradation of the $\mathrm{HO}$ cells in cephalopods revealed a rather unspecific cellular degradation without any clear reference to a specific cell death type. The morphological features of the observed degradation suggest that a necrotic cell death mechanism is most probable in Loligo, Idiosepius and Sepiella (Matsuno \& Ouji, 1988; Arnold \& Singley, 1989; Cyran et al., 2015).

In the present study, the $\mathrm{HO}$ cells of $S$. officinalis display during their degradation the typical vacuolated appearance as commonly described for autophagy (Levine \& Klionsky, 2004). An autophagic vacuole can be morphologically distinguished according to its degradation level in either (a) a double-membraned initial autophagic vacuole $(\mathrm{AVi})$ before lysosome fusion and yet without evidence of degradation, (b) a single-membraned degradative autophagic vacuole (AVd) with highly degraded content or (c) an intermediate level (AVi/d) (Dunn, 1990a, b; Liou et al., 1997). In the present study, we observed exclusively single-membraned AVd's in the HO (Figs. 5B, 6C). Furthermore, there were partly degraded but still recognizable organelles, which can be referred to as type $\mathrm{AVi} / \mathrm{d}$, shortly after fusion with lysosomes.

A similar degradative autophagic process could also be observed in other molluscs (Kiss, 2010) associated with cell degradation (Folkis et al., 1984), antiviral response (Green et al., 2015), depletion of reactive oxygen species (ROS)-damaged proteins and organelles during oxidative stress (Moore et al., 2007; Moore 2008; Abele et al., 2009) or as protection against microbial infection (Moreau et al., 2015).

Although autophagic activity is not intended to eliminate whole cells or even organs in the majority of cases (Kroemer \& Levine, 2008), in the present case the extinction of the entire $\mathrm{HO}$ is clear evidence for the rather seldom observed autophagic cell death (ACD) (Levine \& Yuan, 2005; Berry \& Baehrecke, 2007; Galluzzi et al., 2008). The ultrastructural observations further confirm the expected accompanying features relating to $\mathrm{ACD}$, such as the secondary enlarged Golgi bodies and the loss of microvilli and junctional complexes (Clarke, 1990; Berry \& Baehrecke, 2007; Klepal et al., 2008).

Since autophagic activities require an unimpaired cellular metabolism to assemble phagophores and lysosomes, the following question arises: 'What happens with the remaining cell compartments (nucleus, Golgi, lysosomes) after the autophagic depletion of the cytoplasm?' Our observations did not provide answers to this outstanding issue; perhaps this final degradative period is of markedly short duration. Several studies provide indications that in the case of bulk cell degradation the expression of autophagic genes can induce caspase-dependent apoptotic features (Yousefi et al., 2006; Maiuri et al., 2007; Scott et al., 2007) to clean up cell remnants. In the salivary gland degradation of Drosophila larvae, the steroid hormone ecdysone plays an important role for inducing the expression of both the ATG genes and caspases during tissue remodelling (Berry \& Baehrecke, 2007).

Another observed ACD pathway leads to the activation of RIPK3 (receptor-interacting protein kinase)—dependent necroptosis (Basit et al., 2013; Bonapace et al., 2010). Alternatively, phagocytes are implied to eliminate the remaining cellular parts (Tsujimoto \& Shimizu, 2005). Autophagy also leads to the degradation of catalase, a key enzyme in eliminating ROS (Sohal \& Orr, 1992; Mates et al., 1999); the subsequent ROS accumulation causes membrane peroxidation, the loss of membrane integrity and cell death (Yu et al., 2006).

Apparently, the different molecular pathways have numerous crossing points and collaborate in various combinations, depending on species and requirements as well as the current physiological and metabolic conditions. Current studies on the molecular pathways of ACD and participating molecules (Johansen \& Lamark, 2011; Klionsky et al., 2011, 2012) in several model organisms provide opportunities for upcoming investigations. Future efforts should focus on setting up the protocols for cephalopods.

Nitric oxide synthase

Our results show that after hatching the $\mathrm{HO}$ cells do not exhibit any NOS immunopositivity, which might be the consequence of cell degradation by programmed cell death. On the other hand, this finding together with the presence of NOS and NO in the HO 
at later developmental stages before hatching (Mattiello et al., 2012) could also suggest a possible involvement of NO in preventing cell death signalling (CDS). The action of NO as a cell death inhibitor has likewise been reported in the apical ganglion of the gastropod Ilyanassa obsoleta (Say, 1822), whereby this structure disappears by apoptosis at metamorphosis induction (Leise et al., 2004). Moreover, the increasing NO levels in the $\mathrm{HO}$ before hatching also could be related to the metabolism of the gland, and NO might positively affect the activity of the gland in producing the lytic enzymes necessary to digest the chorion (Fioroni, 1990). Concurrent evaluation of NO and CDS on embryos before, during and after the hatching phase may be helpful to correlate an antagonistic presence in the different tissue regions and at a specific embryonic stage.

\section{Eroded epithelial cells}

The content of the epithelial cells is mainly discharged, both in late embryonic stages (stage 27 onwards) (Fig. 4E), and in hatchlings (Figs. 5A, 6A). This phenomenon has been repeatedly described for other cephalopods (Faussek, 1901; Fioroni, 1963; Cyran et al., 2015) and imaged in further studies (von Orelli, 1959; Boletzky, 1982; Shigeno et al., 2001). Moreover, epithelial abrasions were observed in late embryonic stages on the posterior and dorsal mantle (Fig. 4D, G, H). Other areas as head, ventral and lateral mantle remained intact. Similar observations of a "individual or groups of epithelial cells loss" in relationship to the HO degradation were made for $L$. pealei (Arnold \& Williams-Arnold, 1980; Arnold \& Singley, 1989). Although a fixation-related artefact cannot be excluded, a collapse of the epithelium due to the absence of internal cell content and the insufficient intercellular stability (Fioroni, 1963) in connection with a sliding behaviour of the $\mathrm{HO}$ along the chorion also has to be taken into account.

\section{Ciliary tufts and the ciliated $\mathrm{HO}$ border}

The presence of numerous ciliary tufts on the mantle surface have been associated with the continuous flow in the perivitelline fluid in particular during late embryonic development (von Boletzky, 1979, 1986; Arnold \& Williams-Arnold, 1980), whereas the ciliated bands along the $\mathrm{HO}$ with their short cilia are supposed to provide a locomotory aid during hatching (von Boletzky, 1986) or even a kind of adhesion effect (Arnold \& Singley, 1989). The feather-like expansion of those ciliated bands from stage 26 onwards (Figs. 3D, 4F, I) is suspected to provide a more efficient dispersion of the enzymes along the chorion, similar to the microvilli border in Idiosepiidae (Cyran et al., 2011). The complete regression of both types of ciliary cells within about one day after hatching fits well with their ascribed role in supporting hatching.

Such continuous alterations in the pattern of ciliated cells are related to the changing conditions and requirements during embryonic development such as the growing perivitelline space and the required flow of the perivitelline fluid. Similar observations were made for other decapods such as L. pealei (Arnold \& Williams-Arnold, 1980), where the ciliated cells increasingly form longitudinal bands as the embryo gets closer to hatching. This arrangement generates a flow towards the head, giving support to hatching (Arnold \& Williams-Arnold, 1980). Functionally, the emerging ciliated branches along the dorsal band of $S$. officinalis $\mathrm{HO}$ seem to resemble the ciliary bands in Loligo and may thus be responsible for the hatchsupporting current.

The close association of the ciliary rootlets with the outer membranes of mitochondria (Fig. 8C) illustrates the high energy requirement for generating the perivitelline flow and is strongly reminiscent of the observations in Loligo vulgaris yolk sac envelope (von Boletzky, 1973).

Metallic contents in the hatching gland enzymes

The present study confirms the presence of metals such as $\mathrm{Fe}$ and $\mathrm{Cu}$ within the $\mathrm{HO}$ and connective tissue. The normal mantle epithelium lacks these elements; a metal contamination by the surrounding water could thus be excluded. Also, it is proposed that $\mathrm{Fe}$ and $\mathrm{Cu}$ cannot pass through the egg integument (von Boletzky, 1966, 1973; Paulij et al., 1990), excluding an accumulation during embryonic development. The digestive gland (hepatopancreas) of cephalopods is considered to be the storage site of metals (Miramand \& Bentley, 1992; Bustamante et al., 2002). Measurements of metal concentrations in this gland in S. officinalis (Miramand \& Bentley, 1992; Miramand et al., 2006) and O. vulgaris embryos (Villanueva \& Bustamante, 2006) indicate that Fe and 
Fig. 10 Development phases of the Hoyle organ: the drawing illustrates the overall chronology of the gland development, synthesis, secretion and degradation; details described in the text

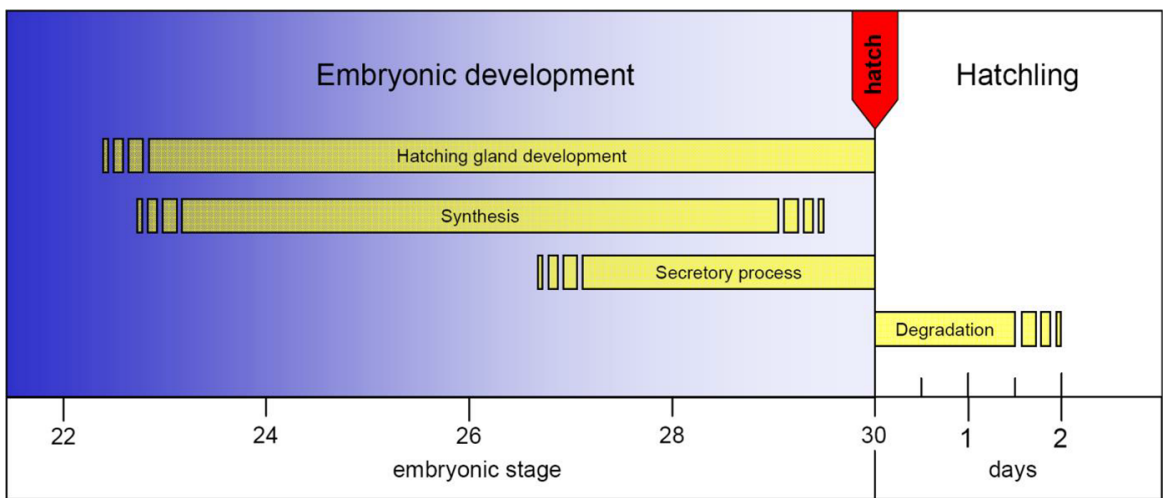

$\mathrm{Cu}$ as well as $\mathrm{Zn}$ occur in significantly higher concentrations than other metals. Also, high amounts of $\mathrm{Cu}$ and $\mathrm{Cu}$-containing proteins are found in mature S. officinalis eggs extracted directly from females ovaries, although the $\mathrm{Cu}$ belongs to a large extent to the Cu-cored hemocyanin (Wolf \& Decleir, 1980). Due to the lack of data, comparison with hatching enzyme-associated metals of other cephalopods is currently not possible. However, in the teleost Oryzias latipes (Temminck \& Schlegel, 1846) a catalytic effect of the metals $\mathrm{Zn}$ and $\mathrm{Mg}(1.24$ and $1.64 \mu \mathrm{g} / \mathrm{mg}$ ) occurs in the hatching enzymes (Yasumasu et al., 1989a). In S. officinalis, the detected $\mathrm{Fe}$ and $\mathrm{Cu}$ ions may achieve a comparable catalytic effect. The assumption of metalloproteases contribution in the $\mathrm{HO}$ of cephalopods is being strengthened by successful inhibition of the enzymatic activity of the hatching medium by the metal chelator EDTA in Loligo vulgaris (Paulij et al., 1992). EDTA rips out and complexes metal ions from the treated medium and so inactivates metalloproteases.

\section{Conclusion}

The results presented above provide an overview of the lifetime of the $\mathrm{HO}$ in $S$. officinalis. The first evidences for cell proliferation are recognizable within the epithelium at embryonic stage 22-23, while first secretory vesicles can be observed at stage 23 and secretion of chorion-digesting enzymes is evident at stage 27 ( Fig. 10). Degradation of the $\mathrm{HO}$ is completed two days after hatching, whereby an autophagic process has been recognized for the first time in cephalopods to explain HO cell degradation. Based upon NOS detection results, NOS immunopositivity was not found in the $\mathrm{HO}$ cells after hatching, suggesting a possible NO role in cell death signalling. Given that the presence of $\mathrm{Fe}$ and $\mathrm{Cu}$ was confirmed in the $\mathrm{HO}$ and connective tissue (but not in the normal mantle tissue) of $S$. officinalis embryos, they may likewise be related to the enzymatic activity of the HO. These results will contribute to the planning of upcoming molecular biological investigations of key cell death proteins to provide a better understanding of the complex processes of cytoplasmic degradation and developmental cell death in cephalopods.

Acknowledgements Open access funding provided by Austrian Science Fund (FWF). The authors would like to particularly thank Dr. Teresa Mattiello for her support and cooperation during the stay at the Stazione Zoologica Anton Dohrn, Naples, Italy. Her experience and knowledge allowed the appropriate collection of the $S$. officinalis embryos used in this research project. This study was kindly funded by the Austrian Science Fund FWF (Project No. P 21135-B17).

Open Access This article is distributed under the terms of the Creative Commons Attribution 4.0 International License (http:// creativecommons.org/licenses/by/4.0/), which permits unrestricted use, distribution, and reproduction in any medium, provided you give appropriate credit to the original author(s) and the source, provide a link to the Creative Commons license, and indicate if changes were made.

\section{References}

Abele, D., T. Brey \& E. Philipp, 2009. Bivalve models of aging and the determination of molluscan lifespans. Experimental Gerontology 44: 307-315.

Arbeitman, M. N., E. E. M. Furlong, F. Imam, E. Johnson, B. H. Null, B. S. Baker, M. A. Krasnow, M. P. Scott, R. W. Davis \& K. P. White, 2002. Gene expression during the life cycle of Drosophila melanogaster. Science 297: 2270-2275. 
Arnold, J. M. \& C. T. Singley, 1989. Ultrastructural changes in the cells of the Hoyle organ during hatching of the squid Loligo pealei. Journal of Cephalopod Biology 1: 1-14.

Arnold, J. M. \& L. D. Williams-Arnold, 1980. Development of the ciliature pattern on the embryo of the squid Loligo pealei: a scanning electron microscope study. Biological Bulletin 159: 102-116.

Ashford, T. P. \& K. R. Porter, 1962. Cytoplasmic components in hepatic cell lysosomes. Journal of Cell Biology 12: 198-202.

Basit, F., S. Cristofanon \& S. Fulda, 2013. Obatoclax (GX15070) triggers necroptosis by promoting the assembly of the necrosome on autophagosomal membranes. Cell Death and Differentiation 20: 1161-1173.

Berry, D. L. \& E. H. Baehrecke, 2007. Growth arrest and autophagy are required for salivary gland cell degradation in Drosophila. Cell 131: 1137-1148.

Boletzky, S., 1982. Developmental aspects of the mantle complex in coleoid cephalopods. Malacologia 23: 165-175.

Bonapace, L., B. C. Bornhauser, M. Schmitz, G. Cario, U. Ziegler, F. K. Niggli, B. W. Schafer, M. Schrappe, M. Stanulla \& J. P. Bourquin, 2010. Induction of autophagydependent necroptosis is required for childhood acute lymphoblastic leukemia cells to overcome glucocorticoid resistance. Journal of Clinical Investigation 120: 1310-1323.

Boucaud-Camou, E., M. Yim \& A. Tresgot, 1985. Feeding and Digestion of Young Sepia officinalis L. (Mollusca: Cephalopoda) during Post-Hatching Development. Vie Milieu 35: 263-266.

Bustamante, P., J. L. Teyssie, S. W. Fowler, O. Cotret, B. Danis, P. Miramand \& M. Warnau, 2002. Biokinetics of zinc and cadmium accumulation and depuration at different stages in the life cycle of the cuttlefish Sepia officinalis. Marine Ecology Progress Series 231: 167-177.

Castellano, I., E. Ercolesi \& A. Palumbo, 2014. Nitric oxide affects ERK signaling through down-regulation of MAP kinase phosphatase levels during larval development of the ascidian Ciona intestinalis. PLoS One 9: e102907.

Clark, S. L., 1957. Cellular Differentiation in the Kidneys of Newborn Mice Studied with the Electron Microscope. Journal of Biophysical and Biochemical Cytology 3: 349-362.

Clarke, P. G. H., 1990. Developmental cell-death - morphological diversity and multiple mechanisms. Anatomy and Embryology 181: 195-213.

Comes, S., A. Locascio, F. Silvestre, M. d'Ischia, G. L. Russo, E. Tosti, M. Branno \& A. Palumbo, 2007. Regulatory roles of nitric oxide during larval development and metamorphosis in Ciona intestinalis. Developmental Biology 306: 772-784.

Cyran, N., W. Klepal \& J. von Byern, 2011. Ultrastructural characterization of the adhesive organ of Idiosepius biserialis and Idiosepius pygmaeus (Mollusca, Cephalopoda). Journal of the Marine Biological Association of the United Kingdom 91: 1499-1510.

Cyran, N., Y. Staedler, J. Schoenenberger, W. Klepal \& J. von Byern, 2013. Hatching glands in cephalopods - a comparative study. Zoologischer Anzeiger 253: 66-82.

Cyran, N., W. Klepal, Y. Staedler, J. Schoenenberger \& J. von Byern, 2015. Alterations in the mantle epithelium during transition from hatching gland to adhesive organ of Idiosepius pygmaeus (Mollusca, Cephalopoda). Mechanisms of Development 135: 43-57.

D'Aniello, A., G. D’Onofrio, M. Pischetola \& J. M. Denuce, 1989. Effect of $\mathrm{pH}$, salinity and $\mathrm{Ca}^{2+}, \mathrm{Mg}^{2+}, \mathrm{K}^{+}$and $\mathrm{SO}^{2+}$ ions on hatching and viability of Loligo vulgaris embryo. Comparative Biochemistry and Physiology - Part A 94: 477-481.

Denuce, J. M. \& A. Formisano, 1982. Circumstantial evidence for an active contribution of Hoyle gland to enzymatic hatching of cephalopod embryos. Archives Internationales de Physiologie de Biochimie et de Biophysique 90: 185-186.

Di Cristo, C., G. Fiore, V. Scheinker, G. Enikolopov, M. d'Ischia, A. Palumbo \& A. Di Cosmo, 2007. Nitric oxide synthase expression in the central nervous system of Sepia officinalis: an in situ hybridization study. European Journal of Neuroscience 26: 1599-1610.

Dunn, W. A., 1990a. Studies on the mechanisms of autophagy formation of the autophagic vacuole. Journal of Cell Biology 110: 1923-1933.

Dunn, W. A., 1990b. Studies on the mechanisms of autophagy maturation of the autophagic vacuole. Journal of Cell Biology 110: 1935-1945.

Eide, D. J., 1998. The molecular biology of metal ion transport in Saccharomyces cerevisiae. Annual Review of Nutrition 18: 441-469.

Eskelinen, E. L., 2008. To be or not to be? Examples of incorrect identification of autophagic compartments in conventional transmission electron microscopy of mammalian cells. Autophagy 4: 257-260.

Eskelinen, E. L., F. Reggiori, M. Baba, A. L. Kovacs \& P. O. Seglen, 2011. Seeing is believing: the impact of electron microscopy on autophagy research. Autophagy 7: 935-956.

Faussek, V., 1901. Untersuchungen über die Entwicklung der Cephalopoden. Mitteilungen aus der Zoologischen Station zu Neapel 14: 83-237.

Fiore, G., A. Poli, A. Di Cosmo, M. d'Ischia \& A. Palumbo, 2004. Dopamine in the ink defence system of Sepia officinalis: Biosynthesis, vesicular compartmentation in mature ink gland cells, nitric oxide (NO)/cGMP-induced depletion and fate in secreted ink. Biochemical Journal 378: 785-791.

Fioroni, P., 1963. Zur embryonalen und postembryonalen Entwicklung der Epidermis bei zehnarmigen Tintenfischen. Verhandlungen der Naturforschenden Gesellschaft in Basel 74: 149-160.

Fioroni, P., 1978. Morphogenese der Tiere: Cephalopoda. VEB Gustav Fischer Verlag, Jena.

Fioroni, P., 1990. Our recent knowledge of the development of the cuttlefish (Sepia officinalis). Zoologischer Anzeiger 224: 1-25.

Folkis, V. V., A. S. Stupina, O. A. Martinenko, S. Toth \& A. I. Timchenko, 1984. Aging of neurons in the mollusc Lymnaea stagnalis. Structure, function and sensitivity to transmitters. Mechanisms of Ageing and Development 25: 91-102.

Galluzzi, L., J. M. Vicencio, O. Kepp, E. Tasdomir, M. C. Maiuri \& G. Kroemer, 2008. To die or not to die: that is the autophagic question. Current Molecular Medicine 8: 78-91. 
Galluzzi, L., I. Vitale, J. M. Abrams, E. S. Alnemri, E. H. Baehrecke, M. V. Blagosklonny, T. M. Dawson, V. L. Dawson, W. S. El-Deiry, S. Fulda, E. Gottlieb, D. R. Green, M. O. Hengartner, O. Kepp, R. A. Knight, S. Kumar, S. A. Lipton, X. Lu, F. Madeo, W. Malorni, P. Mehlen, G. Nunez, M. E. Peter, M. Piacentini, D. C. Rubinsztein, Y. Shi, H. U. Simon, P. Vandenabeele, E. White, J. Yuan, B. Zhivotovsky, G. Melino \& G. Kroemer, 2012. Molecular definitions of cell death subroutines: recommendations of the Nomenclature Committee on Cell Death 2012. Cell Death and Differentiation 19: 107-120.

Gledhill, M., E. P. Achterberg, K. Li, K. N. Mohamed \& M. J. Rijkenberg, 2015. Influence of ocean acidification on the complexation of iron and copper by organic ligands in estuarine waterscopper by organic ligands in estuarine waters. Marine Chemistry 177: 421-433.

Gomi, F., M. Yamamoto \& T. Nakazawa, 1986. Swelling of egg during development of the cuttlefish, Sepiella japonica. Zoological Science 3: 641-645.

Green, T. J., D. Raftos, P. Speck \& C. Montagnani, 2015. Antiviral immunity in marine molluscs. Journal of General Virology 96: 2471-2482.

Guimaraes, C. A. \& R. Linden, 2004. Programmed cell deaths apoptosis and alternative deathstyles. European Journal of Biochemistry 271: 1638-1650.

Jecklin, L., 1934. Beitrag zur Kenntnis der Laichgallerten und der Biologie der Embryonen decapoder Cephalopoden. Revue suisse de zoologie 41: 595-673.

Johansen, T. \& T. Lamark, 2011. Selective autophagy mediated by autophagic adapter proteins. Autophagy 7: 279-296.

Kerr, J. F., A. H. Wyllie \& A. R. Currie, 1972. Apoptosis: a basic biological phenomenon with wide-ranging implications in tissue kinetics. British Journal of Cancer 26: 239-257.

Kiss, T., 2010. Apoptosis and its functional significance in molluscs. Apoptosis 15: 313-321.

Klepal, W., D. Gruber \& B. Pflugpfelder, 2008. Natural cyclic degeneration by a sequence of programmed cell death modes in Semibalanus balanoides (Linnaeus, 1767) (Crustacea, Cirripedia, Thoracica). Zoomorphology 127: 49-58.

Klionsky, D. J., E. H. Baehrecke, J. H. Brumell, C. T. Chu, P. Codogno, A. M. Cuervo, J. Debnath, V. Deretic, Z. Elazar, E. L. Eskelinen, S. Finkbeiner, J. Fueyo-Margareto, D. Gewirtz, M. Jaattela, G. Kroemer, B. Levine, T. J. Melia, N. Mizushima, D. C. Rubinsztein, A. Simonsen, A. Thorburn, M. Thumm \& S. A. Tooze, 2011. A comprehensive glossary of autophagy-related molecules and processes (2nd edition). Autophagy 7: 1273-1294.

Klionsky, D. J., F. C. Abdalla, H. Abeliovich, R. T. Abraham, A. Acevedo-Arozena, K. Adeli, L. Agholme, M. Agnello, P. Agostinis, J. A. Aguirre-Ghiso, H. J. Ahn, O. Ait-Mohamed, S. Ait-Si-Ali, T. Akematsu, S. Akira, H. M. AlYounes, M. A. Al-Zeer, M. L. Albert, R. L. Albin, J. Alegre-Abarrategui, M. F. Aleo, M. Alirezaei, A. Almasan, M. Almonte-Becerril, A. Amano, R. Amaravadi, S. Amarnath, A. O. Amer, N. Andrieu-Abadie, V. Anantharam, D. K. Ann, S. Anoopkumar-Dukie, H. Aoki, N. Apostolova, G. Arancia, J. P. Aris, K. Asanuma, N. Y. O. Asare, H. Ashida, V. Askanas, D. S. Askew, P. Auberger, M. Baba, S. K. Backues, E. H. Baehrecke, B. A. Bahr, X. Y. Bai, Y. Bailly, R. Baiocchi, G. Baldini, W. Balduini, A. Ballabio, B. A. Bamber, E. T. W. Bampton, G. Banhegyi,
C. R. Bartholomew, D. C. Bassham, R. C. Bast, H. Batoko, B. H. Bay, I. Beau, D. M. Bechet, T. J. Begley, C. Behl, C. Behrends, S. Bekri, B. Bellaire, L. J. Bendall, L. Benetti, L. Berliocchi, H. Bernardi, F. Bernassola, S. Besteiro, I. Bhatia-Kissova, X. N. Bi, M. Biard-Piechaczyk, J. S. Blum, L. H. Boise, P. Bonaldo, D. L. Boone, B. C. Bornhauser, K. R. Bortoluci, I. Bossis, F. Bost, J. P. Bourquin, P. Boya, M. Boyer-Guittaut, P. V. Bozhkov, N. R. Brady, C. Brancolini, A. Brech, J. E. Brenman, A. Brennand, E. H. Bresnick, P. Brest, D. Bridges, M. L. Bristol, P. S. Brookes, E. J. Brown, J. H. Brumell, N. Brunetti-Pierri, U. T. Brunk, D. E. Bulman, S. J. Bultman, G. Bultynck, L. F. Burbulla, W. Bursch, J. P. Butchar, W. Buzgariu, S. P. Bydlowski, K. Cadwell, M. Cahova, D. S. Cai, J. Y. Cai, Q. Cai, B. Calabretta, J. Calvo-Garrido, N. Camougrand, M. Campanella, J. Campos-Salinas, E. Candi, L. Z. Cao, A. B. Caplan, S. R. Carding, S. M. Cardoso, J. S. Carew, C. R. Carlin, V. Carmignac, L. A. M. Carneiro, S. Carra, R. A. Caruso, G. Casari, C. Casas, R. Castino, E. Cebollero, F. Cecconi, J. Celli, H. Chaachouay, H. J. Chae, C. Y. Chai, D. C. Chan, E. Y. Chan, R. C. C. Chang, C. M. Che, C. C. Chen, G. C. Chen, G. Q. Chen, M. Chen, Q. Chen, S. S. L. Chen, W. L. Chen, X. Chen, X. M. Chen, X. Q. Chen, Y. G. Chen, Y. Y. Chen, Y. Q. Chen, Y. J. Chen, Z. X. Chen, A. Cheng, C. H. K. Cheng, Y. Cheng, H. Cheong, J. H. Cheong, S. Cherry, R. ChessWilliams, Z. H. Cheung, E. Chevet, H. L. Chiang, R. Chiarelli, T. Chiba, L. S. Chin, S. H. Chiou, F. V. Chisari, C. H. Cho, D. H. Cho, A. M. K. Choi, D. Choi, K. S. Choi, M. E. Choi, S. Chouaib, D. Choubey, V. Choubey, C. T. Chu, T. H. Chuang, S. H. Chueh, T. Chun, Y. J. Chwae, M. L. Chye, R. Ciarcia, M. R. Ciriolo, M. J. Clague, R. S. B. Clark, P. G. H. Clarke, R. Clarke, P. Codogno, H. A. Coller, M. I. Colombo, S. Comincini, M. Condello, F. Condorelli, M. R. Cookson, G. H. C. I. Coppens, R. Corbalan, P. Cossart, P. Costelli, S. Costes, A. Coto-Montes, E. Couve, F. P. Coxon, J. M. Cregg, J. L. Crespo, M. J. Cronje, A. M. Cuervo, J. J. Cullen, M. J. Czaja, M. D'Amelio, A. Darfeuille-Michaud, L. M. Davids, F. E. Davies, M. De Felici, J. F. de Groot, C. A. M. de Haan, L. De Martino, A. De Milito, V. De Tata, J. Debnath, A. Degterev, B. Dehay, L. M. D. Delbridge, F. Demarchi, Y. Z. Deng, J. Dengjel, P. Dent, D. Denton, V. Deretic, S. D. Desai, R. J. Devenish, M. Di Gioacchino, G. Di Paolo, C. Di Pietro, G. DiazAraya, I. Diaz-Laviada, M. T. Diaz-Meco, J. Diaz-Nido, I. Dikic, S. P. Dinesh-Kumar, W. X. Ding, C. W. Distelhorst, A. Diwan, M. Djavaheri-Mergny, S. Dokudovskaya, Z. Dong, F. C. Dorsey \& V. Dosenko, 2012. Guidelines for the use and interpretation of assays for monitoring autophagy. Autophagy 8: 445-544.

Kroemer, G. \& B. Levine, 2008. Autophagic cell death: the story of a misnomer. Nature Reviews Molecular Cell Biology 9: 1004-1010.

Lacoue-Labarthe, T., E. Réveillac, F. Oberhänsli, J. L. Teyssié, R. Jeffree \& J. P. Gattuso, 2011. Effects of ocean acidification on trace element accumulation in the early-life stages of squid Loligo vulgaris. Aquatic Toxicology 105: 207-217.

Leise, E. M., S. C. Kempf, N. R. Durham \& D. J. Gifondorwa, 2004. Induction of metamorphosis in the marine gastropod Ilyanassa obsoleta: $5 \mathrm{HT}$, NO and programmed cell death. Acta Biologica Hungarica 55: 293-300. 
Leist, M. \& M. Jaattela, 2001. Four deaths and a funeral: from caspases to alternative mechanisms. Nature Reviews Molecular Cell Biology 2: 589-598.

Lemaire, J., 1972. Table du dévelopment embryonnaire de Sepia officinalis L. (Mollusque, Céphalopode). Bulletin de la Société Zoologique de France 95: 773-782.

Levine, B. \& D. J. Klionsky, 2004. Development by self-digestion: molecular mechanisms and biological functions of autophagy. Developmental Cell 6: 463-477.

Levine, B. \& J. Y. Yuan, 2005. Autophagy in cell death: an innocent convict? Journal of Clinical Investigation 115(2679-2688): 36.

Liou, W., H. J. Geuze, M. J. H. Geelen \& J. W. Slot, 1997. The autophagic and endocytic pathways converge at the nascent autophagic vacuoles. Journal of Cell Biology 136: 61-70.

Maiuri, M. C., E. Zalckvar, A. Kimchi \& G. Kroemer, 2007. Self-eating and self-killing: crosstalk between autophagy and apoptosis. Nature Reviews Molecular Cell Biology 8: 741-752.

Mates, J. M., C. Perez-Gomez \& I. N. De Castro, 1999. Antioxidant enzymes and human diseases. Clinical Biochemistry 32: 595-603.

Matsuno, A. \& M. Ouji, 1988. Ultrastructural studies on development of the tail gland of a cuttlefish, Sepiella japonica. Development, Growth \& Differentiation 30: 673-680.

Mattiello, T., G. Fiore, E. R. Brown, M. d'Ischia \& A. Palumbo, 2010. Nitric oxide mediates the glutamate-dependent pathway for neurotransmission in Sepia officinalis chromatophore organs. Journal of Biological Chemistry 285: 24154-24163.

Mattiello, T., M. Costantini, B. Di Matteo, S. Livigni, A. Andouche, L. Bonnaud \& A. Palumbo, 2012. The dynamic nitric oxide pattern in developing cuttlefish Sepia officinalis. Developmental Dynamics 241: 390-402.

Mattiello, T., M. d'Ischia \& A. Palumbo, 2013. Nitric oxide in chromatic body patterning elements of Sepia officinalis. Journal of Experimental Marine Biology and Ecology 447: 128-131.

Mcphee, C. K., M. A. Logan, M. R. Freeman \& E. H. Baehrecke, 2010. Activation of autophagy during cell death requires the engulfment receptor Draper. Nature 465: 1093-1096.

Migliaccio, O., I. Castellano, G. Romano \& A. Palumbo, 2014. Stress response to cadmium and manganese in Paracentrotus lividus developing embryos is mediated by nitric oxide. Aquatic Toxicology 156: 125-134.

Miramand, P. \& D. Bentley, 1992. Concentration and distribution of heavy metals in tissues of two cephalopods, Eledone cirrhosa and Sepia officinalis from the French coast of the English channel. Marine Biology 114: 407-414.

Miramand, P., P. Bustamante, D. Bentley \& N. Koueta, 2006. Variation of heavy metal concentrations ( $\mathrm{Ag}, \mathrm{Cd} \mathrm{Co}, \mathrm{Cu}$, $\mathrm{Fe}, \mathrm{Pb}, \mathrm{V}$, and $\mathrm{Zn}$ ) during the life cycle of the common cuttlefish Sepia officinalis. Science of the Total Environment 361: 132-143.

Moore, M. N., 2008. Autophagy as a second level protective process in conferring resistance to environmentally-induced oxidative stress. Autophagy 4: 254-256.

Moore, M. N., A. Viarengo, P. Donkin \& A. J. S. Hawkins, 2007. Autophagic and lysosomal reactions to stress in the hepatopancreas of blue mussels. Aquatic Toxicology 84: 80-91.

Moreau, P., K. Moreau, A. Segarra, D. Tourbiez, M. A. Travers, D. C. Rubinsztein \& T. Renault, 2015. Autophagy plays an important role in protecting Pacific oysters from OsHV-1 and Vibrio aestuarianus infections. Autophagy 11: 516-526.

Morel, F. M. M., A. J. Milligan \& M. A. Saito, 2003. Marine bioinorganic chemistry: the role of trace metals in the oceanic cycles of major nutrients. In Elderfield, H. (ed.), Treatise on Geochemistry. Elsevier Science, Oxford: 113-143.

Nakakoshi, M., H. Nishioka \& E. Katayama, 2011. New versatile staining reagents for biological transmission electron microscopy that substitute for uranyl acetate. Journal of Electron Microscopy 60: 401-407.

Nixon, M. \& K. Mangold, 1998. The early life of Sepia officinalis, and the contrast with that to Octopus vulgaris. Journal of Zoology, London 245: 407-421.

Novikoff, A. B. \& E. Essner, 1962. Cytolysomes and mitochondrial degeneration. Journal of Cell Biology 15: 140-146.

O'Brian, C. E., 2017. Behavioral development in embryonic and early juvenile cuttlefish (Sepia officinalis). Developmental Psychobiology 59: 145-160.

Ogawa, N. \& Y. Ohi, 1968. On the chorion and the hatching enzyme of the medaka, Oryzias latipes. Zoological Magazine 77: 151-156.

Palumbo, A., 2005. Nitric oxide in marine invertebrates: a comparative perspective. Comparative Biochemistry and Physiology Series A Molecular \& Integrative Physiology 142: 241-248.

Palumbo, A., A. Poli, A. DiCosmo \& M. d Ischia, 2000. NMethyl-D-aspartate receptor stimulation activates tyrosinase and promotes melanin synthesis in the Ink gland of the cuttlefish Sepia officinalis through the nitric oxide/ cGMP signal transduction pathway - a novel possible role for glutamate as physiologic activator of melanogenesis. Journal of Biological Chemistry 275: 16885-16890.

Paulij, W. P., H. C. C. M. Verhoof \& J. M. Denuce, 1992. Partial purification and characterization of Loligo vulgaris hatching enzyme obtained from hatching medium. Comparative Biochemistry and Physiology Series B 101: 617-622.

Paulij, W. P., W. Zurburg, J. M. Denuce \& E. J. Vanhannen, 1990. The effect of copper on the embryonic development and hatching of Sepia-Officinalis. Archives of Environmental Contamination and Toxicology 19: 797-801.

Pörtner, H. O. \& S. Zielinski, 1998. Environmental constraints and the physiology of performance in squids. African Journal of Marine Science 20: 207-217.

Reynolds, E. S., 1963. The use of lead citrate at high $\mathrm{pH}$ as an electron-opaque stain in electron microscopy. Journal of Cell Biology 17: 208-212.

Scott, R. C., G. Juhasz \& T. P. Neufeld, 2007. Direct induction of autophagy by Atg1 inhibits cell growth and induces apoptotic cell death. Current Biology 17: 1-11.

Shigeno, S., H. Kidokoro, T. Goto, K. Tsuchiya \& S. Segawa, 2001. Early ontogeny of the japanese common squid Todarodes pacificus (Cephalopoda, Ommastrephidae) with special reference to its Characteristic Morphology and 
Ecological Significance. Zoological Science 18: 1011-1026.

Sohal, R. S. \& W. C. Orr, 1992. Relationship between antioxidants, prooxidants, and the aging process. Annals of the New York Academy of Sciences 663: 74-84.

Stockdale, A., E. Tipping, E. Lofts \& R. J. G. Mortimer, 2016. Effect of ocean acidification on organic and inorganic speciation of trace metals. Environmental Science \& Technology 50: 1906-1913.

Thumm, M., R. Egner, B. Koch, M. Schlumpberger, M. Straub, M. Veenhuis \& D. H. Wolf, 1994. Isolation of autophagocytosis mutants of Saccharomyces cerevisiae. FEBS Letters 349: 275-280.

Tsujimoto, Y. \& S. Shimizu, 2005. Another way to die: autophagic programmed cell death. Cell Death and Differentiation 12: 1528-1534.

Tsukada, M. \& Y. Ohsumi, 1993. Isolation and characterization of autophagy-defective mutants of Saccharomyces cerevisiae. FEBS Letters 333: 169-174.

Vidal, E. A., R. Villanueva, J. P. Andrade, I. G. Gleadall, J. Iglesias, N. Koueta, C. Rosas, S. Segawa, B. Grasse, R. M. Franco-Santos, C. B. Albertin, C. Caamal-Monsreal, M. E. Chimal, E. Edsinger-Gonzales, P. Gallardo, P. C. Le, C. Pascual, K. Roumbedakis \& J. Wood, 2014. Cephalopod culture: current status of main biological models and research priorities. Advances in Marine Biology 67: 1-98.

Villanueva, R. \& P. Bustamante, 2006. Composition in essential and non-essential elements of early stages of cephalopods and dietary effects on the element profiles of Octopus vulgaris paralarvae. Aquaculture 261: 225-240.

von Boletzky, S., 1966. Zum Schlüpfen von Octopus vulgaris Lam. Verhandlungen der Naturforschenden Gesellschaft in Basel 77: 164-170.

von Boletzky, S., 1973. Association of mitochondria with ciliary rootlets in squid embryos. Cytobiologie 8: 164-167.

von Boletzky, S., 1979. Ciliary locomotion in squid hatching. Experientia 35: 1051-1053.

von Boletzky, S., 1986. Encapsulation of cephalopod embryos: a search for functional correlations. American Malacological Bulletin 4: 217-227.

von Boletzky, S., 1991. The terminal spine of sepiolid hatchlings: its development and functional morphology (Mollusca: Cephalopoda). Bulletin of Marine Science 49: 107-112.

von Boletzky, S., 1998. Cephalopod eggs and egg masses. Oceanography and Marine Biology: An Annual Review 36: 341-370.

von Boletzky, S., 2003. Biology of early life stages in cephalopod molluscs. Advances in Marine Biology 44: 143-203.

von Boletzky, S., 2012. Hatch-as hatch-can: tricks of the trade in coleoid hatchlings (Mollusca: Cephalopoda). Neues Jahrbuch für Geologie und Paläontologie-Abhandlungen 266: 67-76. von Boletzky, S., A. Andouche \& L. Bonnaud-Ponticelli, 2016. A developmental table of embryogenesis in Sepia officinalis. Vie et Milieu-Life \& Environment 66: 11-23.

von Byern, J., A. Kerbl, M. T. Nödl, G. Bello, Y. Staedler, J. Schoenenberger \& N. Cyran, 2016. Spine formation as a hatching tool in Euprymna scolopes (Mollusca, Cephalopoda, Sepiolidae). Malacologia 59: 231-238.

von Orelli, M., 1959. Über das Schlüpfen von Octopus vulgaris, Sepia officinalis und Loligo vulgaris. Revue Suisse de Zoologie 66: 330-343.

Wintrebert, P., 1928. ĹEclosion par digestion de la coque chez les poissons, les amphibiens et les céphalopodes dibranchiaux décapodes. Comptes rendus de l'Association des Anatomistes Nancy 1928: 496-503.

Wolf, G. \& W. Decleir, 1980. A study of copper and copper proteins in the eggs of Sepia officinalis L. Annales de la Société royale zoologique de Belgique 110: 115-122.

Wollesen, T., R. Loesel \& A. Wanninger, 2009. Pygmy squid and giant brains: mapping the complex cephalopod CNS by phalloidin staining of vibratome sections and whole-mount preparations. Journal of Neuroscience Methods 179: 63-67.

Wyllie, A. H., J. F. Kerr \& A. R. Currie, 1980. Cell death: the significance of apoptosis. International Review of Cytology 68: 251-306.

Yamagami, K., 1973. Some enzymological properties of a hatching enzyme (chorionase) isolated from the fresh-water teleost, Oryzias latipes. Comparative Biochemistry and Physiology Series B Biochemistry \& Molecular Biology 46: 603-616.

Yasumasu, S., I. Iuchi \& K. Yamagami, 1988. Medaka hatching enzyme consists of 2 kinds of proteases which act cooperatively. Zoological Science 5: 191-195.

Yasumasu, S., I. Iuchi \& K. Yamagami, 1989a. Isolation and some properties of low choriolytic enzyme (LCE), a component of the hatching enzyme of the teleost, Oryzias latipes. Journal of Biochemistry 105: 212-218.

Yasumasu, S., I. Iuchi \& K. Yamagami, 1989b. Purification and partial characterization of high choriolytic enzyme (HCE), a component of the hatching enzyme of the teleost Oryzias latipes. Journal of Biochemistry 105: 204-211.

Yousefi, S., R. Perozzo, I. Schmid, A. Ziemiecki, T. Schaffner, L. Scapozza, T. Brunner \& H. U. Simon, 2006. Calpainmediated cleavage of Atg5 switches autophagy to apoptosis. Nature Cell Biology 8: 1124-1132.

Yu, L., F. Y. Wan, S. Dutta, S. Welsh, Z. H. Liu, E. Freundt, E. H. Baehrecke \& M. Lenardo, 2006. Autophagic programmed cell death by selective catalase degradation. Proceedings of the National Academy of Sciences of the United States of America 103: 4952-4957.

Yung Ko Ching, M., 1930. Contribution á letude cytologique de lovogenese, du developpment et de quelques organes chez les cephalopodes. Annales de ĹInstitut Oceanographique 7: $300-364$. 